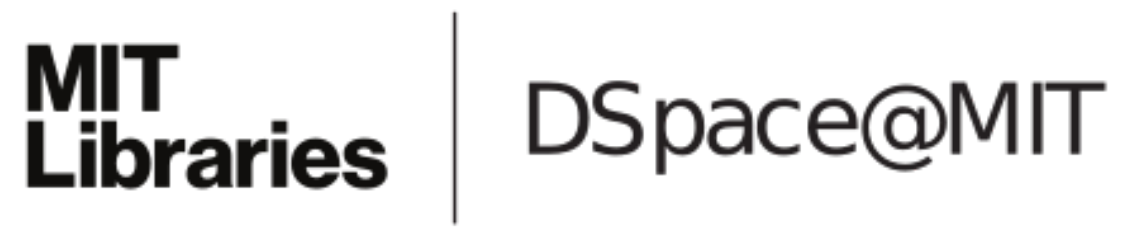

\author{
MIT Open Access Articles
}

Durability of Output and Expected Stock Returns

The MIT Faculty has made this article openly available. Please share how this access benefits you. Your story matters.

Citation: Gomes, João F., Leonid Kogan, and Motohiro Yogo. "Durability of Output and Expected Stock Returns." Journal of Political Economy 117.5 (2009) : 941-986. () 2009 by The University of Chicago

As Published: http://dx.doi.org/10.1086/648882

Publisher: University of Chicago Press

Persistent URL: http://hdl.handle.net/1721.1/65095

Version: Final published version: final published article, as it appeared in a journal, conference proceedings, or other formally published context

Terms of Use: Article is made available in accordance with the publisher's policy and may be subject to US copyright law. Please refer to the publisher's site for terms of use. 


\title{
Durability of Output and Expected Stock Returns
}

\author{
João F. Gomes \\ University of Pennsylvania and London Business School \\ Leonid Kogan
}

Massachusetts Institute of Technology and National Bureau of Economic Research

\section{Motohiro Yogo}

University of Pennsylvania and National Bureau of Economic Research

The demand for durable goods is more cyclical than that for nondurable goods and services. Consequently, the cash flows and stock returns of durable-good producers are exposed to higher systematic risk. Using the benchmark input-output accounts of the National Income and Product Accounts, we construct portfolios of durable-good, nondurable-good, and service producers. In the cross section, an investment strategy that is long on the durable-good portfolio and short on the service portfolio earns a risk premium exceeding 4 percent annually. In the time series, an investment strategy that is long on the durable-good portfolio and short on the market portfolio earns a countercyclical risk premium. We explain these findings in a general equilibrium asset-pricing model with endogenous production.

For comments and discussions, we thank James Choi, Lars Hansen, John Heaton, Xiaoji Lin, Monika Piazzesi, Valery Polkovnichenko, Robert Stambaugh, Selale Tuzel, Stijn Van Nieuwerburgh, Lu Zhang, and three anonymous referees. We also thank seminar participants at Brigham Young University, Federal Reserve Board, Goldman Sachs Asset Management, London Business School, New York University, PanAgora Asset Management, Stanford University, University of British Columbia, University of California, Berkeley, University of Chicago, University of Pennsylvania, University of Tokyo, University of Utah, University of Washington, the 2006 North American winter meeting of the Econometric Society, the 2006 New York University Stern Five-Star Conference on Research in Finance, the 2007 Utah Winter Finance Conference, the 2007 annual meeting of the Society for

[ Journal of Political Economy, 2009, vol. 117, no. 5]

(C) 2009 by The University of Chicago. All rights reserved. 0022-3808/2009/11705-0005\$10.00 


\section{Introduction}

The cross section of stock returns has been a subject of considerable research in financial economics. A key finding in this literature is that variation in accounting and financial variables across stocks generates puzzlingly large variation in average returns. ${ }^{1}$ In contrast, variation in measured systematic risk across stocks generates surprisingly little variation in average returns. For example, classic studies of the capital asset pricing model (CAPM) have found no variation in average returns across portfolios of stocks sorted by the market beta (Black, Jensen, and Scholes 1972; Fama and MacBeth 1973; Fama and French 1992).

This paper shows that durability of a firm's output is a characteristic that is related to systematic risk and therefore is priced in the cross section of stock returns. Our approach builds on the core intuition of the consumption-based CAPM, which dictates that assets with higher exposure to systematic risk command higher risk premia. Because some components of aggregate consumption are more cyclical than others, firms producing the more cyclical components must command higher risk premia. In particular, we argue theoretically and verify empirically that firms that produce durable goods are exposed to higher systematic risk than those that produce nondurable goods and services. An appealing aspect of our approach is that we classify firms on the basis of an easily observable and economically meaningful characteristic related to systematic risk instead of accounting and financial variables that have a tenuous relation with risk. While durability may not be the only aspect of a firm's output that determines its exposure to systematic risk, our success raises hope for identifying other proxies for systematic risk that are tied to variation in expected stock returns.

To identify the durability of each firm's output, we first develop a novel industry classification using the benchmark input-output accounts of the National Income and Product Accounts. Our classification essentially identifies each standard industrial classification (SIC) industry by its primary contribution to final demand. We then sort firms into portfolios representing the three broad categories of personal consumption expenditures: durable goods, nondurable goods, and services. Because these portfolios have cash flows that are economically tied to

Economic Dynamics, the 2007 NBER Summer Institute Capital Markets and the Economy Workshop, the 2008 annual meeting of the American Finance Association, the 2008 NBER Summer Institute Asset Pricing Workshop, and the 2009 London School of Economics Financial Markets Group Conference on Housing, Financial Markets, and the Macroeconomy.

${ }^{1}$ A partial list of accounting and financial variables that are known to be related to average stock returns includes market equity (Banz 1981), earnings yield (Basu 1983), book-to-market equity (Rosenberg, Reid, and Lanstein 1985; Fama and French 1992), leverage (Bhandari 1988), and past returns (Jegadeesh and Titman 1993). 
aggregate consumption, they can be interpreted as consumption riskmimicking portfolios in the sense of Breeden, Gibbons, and Litzenberger (1989). Because the benchmark input-output accounts allow us to sort firms precisely along a dimension of economic interest, our portfolios are more appropriate for studying cash flows and stock returns than those based on more common (and somewhat arbitrary) industry classifications.

We use the industry portfolios to document four new facts in the cross section of cash flows and stock returns.

1. The cash flows of durable-good producers, relative to those of service producers and nondurable-good producers, are more volatile and more correlated with aggregate consumption.

2. The returns on the durable-good portfolio are higher on average and more volatile. Over the 1927-2007 sample period, an investment strategy that is long on the durable-good portfolio and short on the service portfolio earned an average annual return exceeding 4 percent.

3. The cash flows of durable-good producers are conditionally more volatile whenever the durable expenditure-stock ratio (i.e., the ratio of aggregate durable expenditure to the stock of durables) is low, which generally coincides with recessions.

4. The returns on the durable-good portfolio are more predictable. An investment strategy that is long on the durable-good portfolio and short on the market portfolio has countercyclical expected returns, reliably predicted by the durable expenditure-stock ratio.

The first finding is not surprising in light of the well-known fact that the aggregate expenditure on durable goods is more cyclical than that on nondurable goods and services. Therefore, it is merely a statement of the fact that our industry classification, based on the benchmark input-output accounts, reliably sorts firms on the basis of the characteristic of their output. Although the second finding may seem like a natural implication of the first, it is surprising because empirical research in asset pricing has produced scarce evidence on an economic (in contrast to merely statistical) relation between cash flow risk and return in the cross section of stocks. The third and fourth findings are less obvious implications of durability that we discovered only after developing a model that guided our search.

We develop a general equilibrium asset-pricing model to demonstrate that the durability of output is a source of systematic risk that is priced in both the cross section and the time series of expected stock returns. We start with a representative household that has utility over a nondurable and a durable consumption good. We then endogenize both household consumption and firm cash flows through a dynamic pro- 
duction economy with two types of firms, a nondurable-good producer and a durable-good producer. The joint endogeneity of production and cash flows allows us to explicitly link the durability of output to the amount of systematic risk faced by firms, in contrast to a model in which cash flows vary exogenously.

The basic mechanism of our model is fairly intuitive. A proportional change in the service flow (or the stock) of durable goods requires a much larger proportional change in the expenditure on durable goods. This amplifying effect is analogous to that present in the relation between investment and the capital stock. As a result, the demand for durable goods is more cyclical and volatile than that for nondurable goods and services, which implies that the cash flows and stock returns of durable-good producers have higher risk. An additional implication of the model is that the amplifying effect must be relatively large when the existing stock of durables is high relative to current demand. Consequently, the difference in the conditional cash flow risk between durable-good producers and nondurable-good producers is relatively high when the existing stock of durables is high relative to current demand. This mechanism leads to a testable implication that the durable expenditure-stock ratio predicts cross-sectional differences in the conditional moments of cash flows and stock returns, which is the basis for the third and fourth findings above.

We assess the general equilibrium model in two ways. First, we calibrate the model to match the demand for both nondurable and durable goods as well as the inventory of finished durable goods in macroeconomic data. We show that the model generates an empirically realistic amount of cyclical variation in cash flows. We find that the calibrated model generates variation in risk premia across firms and over time that is consistent with the empirical evidence. Second, we estimate the household's Euler equations, which hold regardless of specific assumptions about the production technology. We find that the household's intertemporal marginal rate of substitution prices our industry portfolios in the sense that the $J$-test fails to reject the model. Our findings suggest that, at the minimum, a two-factor model in nondurable consumption growth and the market return is necessary to explain the cross section of returns on the industry portfolios. In particular, the standard CAPM fails to price our industry portfolios.

Our work is part of a recent effort to link expected stock returns to fundamental aspects of firm heterogeneity. One branch of the literature shows that the size and book-to-market effects arise naturally from optimal production and investment decisions (e.g., Berk, Green, and Naik 1999; Kogan 2001, 2004; Gomes, Kogan, and Zhang 2003; Carlson, Fisher, and Giammarino 2004). A limitation of these earlier studies is that the underlying determinants of stock returns are often difficult to 
measure, and perhaps more important, they rely on differences between firms that are not true primitives of the economic environment. Key ingredients in these models include heterogeneity in fixed costs of operation, the degree of irreversibility in capital, and the volatility of cash flows. Partly in response, Gourio (2005) and Tuzel (2005) focus on more readily identifiable sources of firm heterogeneity, such as differences in their production technology or the composition of their physical assets. This paper is in the same spirit, but we focus on heterogeneity in the characteristics of the output instead of the technology or the inputs.

The remainder of the paper proceeds as follows. Section II explains our industry classification based on the benchmark input-output accounts and documents the construction of our industry portfolios. We then lay out the empirical foundations of the paper by documenting key empirical properties of portfolios sorted by the durability of output. In Section III, we set up a general equilibrium asset-pricing model, based on a two-sector production economy, that incorporates the notion of firm heterogeneity based on the durability of output. In Section IV, we calibrate the general equilibrium model to match macroeconomic data and examine its quantitative implications for asset prices. In Section V, we estimate the household's Euler equations using cross-sectional and time-series moments of consumption and industry portfolio returns and test for an empirical relation between risk and return. Section VI presents conclusions.

\section{Portfolios Sorted by the Durability of Output}

Most empirical studies in asset pricing are based on portfolios constructed along fairly arbitrary dimensions. On the one hand, portfolios sorted by characteristics directly related to stock prices or returns generate large variation in average returns but little meaningful variation in risk (Daniel and Titman 1997). On the other hand, industry portfolios based on somewhat subjective industry classifications generate little variation in average returns but puzzling variation in risk (Fama and French 1997).

In this paper, we propose a new set of portfolios that is related to macroeconomic risk, carefully building a connection between consumption expenditures and cash flows. As a result, we believe that our portfolios provide a much more appropriate benchmark for evaluating the performance of existing asset-pricing models. The notion of synthesizing assets that mimic macroeconomic risk is hardly new (e.g., Shiller 1993). However, our methodology differs from the conventional procedure that starts with a universe of assets and then estimates portfolio weights that create maximal correlation with the economic variable of interest (e.g., Breeden et al. 1989; Lamont 2001). Our approach does 
not require estimation, and more important, the cash flows are economically (and not just statistically) linked to consumption risk.

\section{A. Industry Classification Based on the Benchmark Input-Output Accounts}

The National Income and Product Accounts classify personal consumption expenditures into the following three categories, ordered in decreasing degree of durability.

- Durable goods are "commodities that can be stored or inventoried and have an average service life of at least three years." This category consists of furniture and household equipment, motor vehicles and parts, and other durable goods.

- Nondurable goods are "commodities that can be stored or inventoried and have an average service life of at most three years." This category consists of clothing and shoes, food, fuel oil and coal, gasoline and oil, and other nondurable goods.

- Services are "commodities that cannot be stored and that are consumed at the place and time of purchase." This category consists of household operation, housing, medical care, net foreign travel, personal business, personal care, private education and research, recreation, religious and welfare activities, and transportation.

Our empirical analysis requires a link from industries, identified by the four-digit SIC code, to the various components of personal consumption expenditures. Because such a link is not readily available, we create our own using the 1987 benchmark input-output accounts (Bureau of Economic Analysis 1994). ${ }^{2}$ The benchmark input-output accounts identify how much output each industry contributes to the four broad categories of final demand: personal consumption expenditures, gross private investment, government expenditures, and net exports of goods and services. Within personal consumption expenditures, the benchmark input-output accounts also identify how much output each industry contributes to the three categories of durability. On the basis of these data, we assign each industry to the category of final demand to which it has the highest value added: personal consumption expenditures on durable goods, personal consumption expenditures on nondurable goods, personal consumption expenditures on services, investment, government expenditures, and net exports.

The national accounts classify expenditure on owner-occupied hous-

${ }^{2}$ We use the 1987 benchmark input-output accounts because the industry identifiers in the Center for Research in Security Prices (CRSP) database are based on the 1987 SIC codes. However, we have examined the benchmark input-output accounts from other available years $(1958,1963,1967,1977,1992$, and 1997) to verify that the industry classification is stable over time. 
ing as part of private residential fixed investment instead of personal consumption expenditures. In the publicly available files, the benchmark input-output accounts do not have a breakdown of private fixed investment into residential and nonresidential. Therefore, we are forced to classify industries whose primary output is owner-occupied housing as part of investment instead of personal consumption expenditures on durable goods. SIC code 7000 (hotels and other lodging places) is the only industry that has direct output to housing services in the benchmark input-output accounts. We therefore keep housing services as part of personal consumption expenditures on services.

Appendix A contains further details on the construction of the industry classification. The industry classification is available in spreadsheet format from Motohiro Yogo's Web site (http://finance.wharton .upenn.edu/ yogo/).

\section{B. Construction of the Industry Portfolios}

The universe of stocks is ordinary common equity traded in the New York Stock Exchange (NYSE), American Stock Exchange (AMEX), or Nasdaq, which are recorded in the CRSP Monthly Stock Database. In June of each year $t$, we sort the universe of stocks into five industry portfolios on the basis of their SIC code: services, nondurable goods, durable goods, investment goods, and other industries. Other industries include the wholesale, retail, and financial sectors as well as industries whose primary output is to government expenditures or net exports. We use the SIC code from Compustat if available (starting in 1983) and the SIC code from CRSP otherwise. We first search for a match at the four-, then at the three-, and finally at the two-digit SIC code. Once the portfolios are formed, we track their value-weighted returns from July of year $t$ through June of year $t+1$. We compute annual portfolio returns by compounding monthly returns.

We compute dividends for each stock on the basis of the difference of holding period returns with and without dividends. Since 1971, we augment dividends with equity repurchases from Compustat's statement of cash flows (see Boudoukh et al. 2007). We assume that the repurchases occur at the end of each fiscal year. Monthly dividends for each portfolio are simply the sum of dividends across all stocks in the portfolio. We compute annual dividends in December of each year by accumulating monthly dividends, assuming that intermediate (January through November) dividends are reinvested in the portfolio until the end of the calendar year. We compute dividend growth and the dividend yield for each portfolio on the basis of a "buy and hold" investment strategy starting in 1927.

Since 1951, we compute other characteristics for each portfolio using 
TABLE 1

Characteristics of the Industry Portfolios

\begin{tabular}{|c|c|c|c|c|c|}
\hline Variable & Services & Nondurables & Durables & Investment & Other \\
\hline & \multicolumn{5}{|c|}{ A. 1927-2007 Sample Period } \\
\hline Number of firms & 410 & 426 & 190 & 633 & 1,273 \\
\hline Percent of market equity & 14.6 & 35.2 & 15.5 & 17.7 & 17.0 \\
\hline Dividend yield (\%) & 5.4 & 4.6 & 5.1 & 4.0 & 4.1 \\
\hline \multirow[t]{2}{*}{ Book-to-market equity (\%) } & 112.1 & 66.4 & 62.7 & 76.8 & 62.8 \\
\hline & \multicolumn{5}{|c|}{ B. 1951-2007 Sample Period } \\
\hline Number of firms & 534 & 524 & 233 & 826 & 1,734 \\
\hline Percent of market equity & 10.1 & 39.1 & 15.3 & 18.2 & 17.3 \\
\hline Dividend yield (\%) & 5.3 & 4.4 & 4.8 & 3.5 & 3.7 \\
\hline Book-to-market equity (\%) & 87.3 & 53.4 & 62.4 & 56.4 & 60.6 \\
\hline Market leverage $(\%)$ & 51.6 & 30.2 & 47.5 & 34.2 & 63.7 \\
\hline
\end{tabular}

the subset of firms for which the relevant data are available from Compustat. Book-to-market equity is book equity at the end of fiscal year $t$ divided by the market equity in December of year $t$. We construct book equity data as a merge of Compustat and historical data from Moody's manuals, downloaded from Kenneth French's Web site. We follow the procedure described in Davis, Fama, and French (2000) for the computation of book equity. Market leverage is liabilities at the end of fiscal year $t$ divided by the sum of liabilities and market equity in December of year $t$. Operating income is sales minus the cost of goods sold. We compute the annual growth rate of sales and operating income from year $t$ to $t+1$ on the basis of the subset of firms that are in the portfolio in both years.

\section{Characteristics of the Industry Portfolios}

Table 1 reports some basic characteristics of the five industry portfolios. We focus our attention on the first three portfolios, which represent personal consumption expenditures. To get a sense of the size of the portfolios, we report the average number of firms and the average share of total market equity that each portfolio represents. In the 1927-2007 sample period, the service portfolio represents 14.6 percent, the nondurable-good portfolio represents 35.2 percent, and the durable-good portfolio represents 15.5 percent of total market equity. The service portfolio has the highest average dividend yield and the nondurablegood portfolio has the lowest. The service portfolio has the highest average book-to-market equity and the durable-good portfolio has the lowest. 
In the 1951-2007 sample period, the service portfolio has the highest average book-to-market equity and the nondurable-good portfolio has the lowest. Similarly, the service portfolio has the highest average market leverage, and the nondurable-good portfolio has the lowest. These patterns show that durability of output is not a characteristic that is directly related to common accounting and financial variables such as book-tomarket equity and market leverage.

\section{Link to Aggregate Consumption}

If our industry classification successfully identifies durable-good producers, the total sales of firms in the durable-good portfolio should be empirically related to the aggregate expenditure on durable goods. In figure 1, we plot the annual growth rate of sales for four portfolios representing firms that produce services, nondurable goods, durable goods, and investment goods. The dashed line in all four panels, shown for the purposes of comparison, is the annual growth rate of real durable expenditure from the National Income and Product Accounts. As figure $1 C$ demonstrates, the correlation between the sales of durable-good producers and durable expenditure is almost perfect. This evidence suggests that our industry classification successfully identifies durablegood producers.

Table 2 reports more comprehensive evidence for the relation between cash flow growth and consumption growth. Panel A reports descriptive statistics for the annual growth rate of sales for the industry portfolios. In addition, the table reports the correlation between sales growth and the growth rate of real service consumption, real nondurable consumption, and real durable expenditure. (See App. B for a detailed description of the consumption data.) Durable-good producers have sales that are more volatile than those of service producers and nondurable-good producers with a standard deviation of 7.80 percent. The sales of durable-good producers have a correlation of .72 with durable expenditure, confirming the visual impression in figure 1 . The sales of both service producers and nondurable-good producers have a relatively low correlation with nondurable and service consumption. An explanation for this low correlation is that a large share of nondurable and service consumption is produced by private firms, nonprofit firms, and households that are not part of the CRSP database.

There is a potential accounting problem in the aggregation of sales across firms. Conceptually, aggregate consumption in the national accounts is the sum of value added across all firms, which is sales minus the cost of intermediate inputs. Therefore, the sum of sales across firms can lead to double accounting of the cost of intermediate inputs. We therefore compute the operating income for each firm, defined as sales 
A.

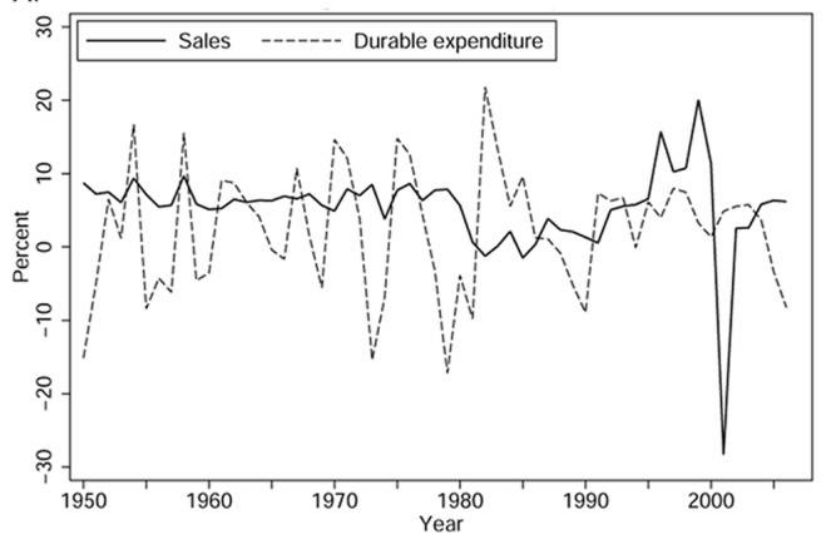

B.

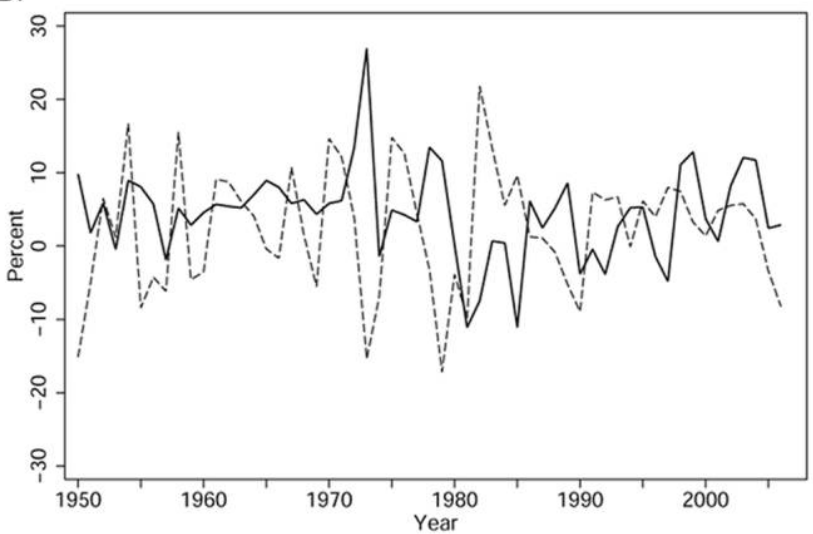

FIG. 1.- Log annual growth rate of sales for the industry portfolios. A, Sales growth of service producers. $B$, Sales growth of nondurable-good producers. $C$, Sales growth of durable-good producers. $D$, Sales growth of investment-good producers. Sales are from Compustat and are deflated by the price index for nondurable goods and services. The dashed line in each panel is the log growth rate of real durable expenditure (i.e., the sum of personal consumption expenditures on durable goods and private residential fixed investment). The sample period is 1951-2007.

minus the cost of goods sold. Unfortunately, the cost of goods sold in Compustat includes wages and salaries in addition to the cost of intermediate inputs. However, this adjustment would eliminate double accounting and potentially lead to a better correspondence between the output of Compustat firms and aggregate consumption.

Panel B reports descriptive statistics for the annual growth rate of operating income for the industry portfolios. The standard deviation of operating income growth for both service producers and nondurable- 
C.

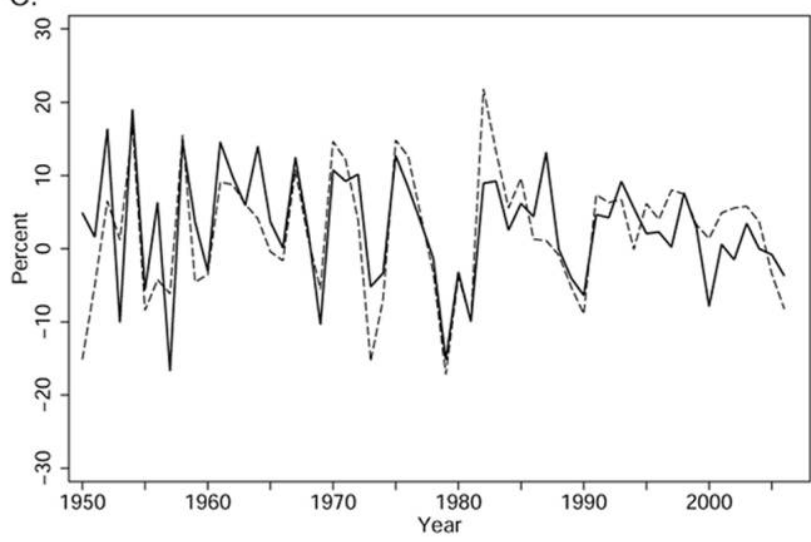

D.

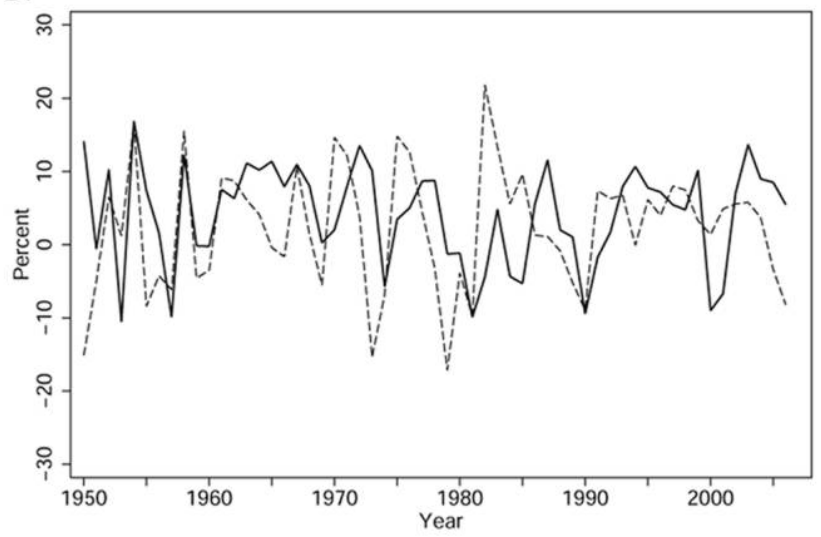

Fig. 1.-Continued

good producers is less than 6 percent, compared to 12.11 percent for durable-good producers. These differences mirror the large differences in the volatility of real aggregate quantities (reported in table 9 below). In the 1951-2007 sample period, the standard deviation of nondurable and service consumption growth is 1.16 percent, compared to 8.37 percent for durable expenditure growth. In comparison to sales, the operating incomes of service producers and nondurable-good producers have a somewhat higher correlation with nondurable and service consumption. The correlation between the operating income of service producers and service consumption is .15 . The correlation between the operating income of nondurable-good producers and nondurable consumption is .22. Finally, the correlation between the operating income of durable-good producers and durable expenditure is .75. 
TABLE 2

Cash Flow Growth for the Industry Portfolios

\begin{tabular}{|c|c|c|c|}
\hline Statistic & Services & Nondurables & Durables \\
\hline & \multicolumn{3}{|c|}{ A. Sales Growth } \\
\hline Mean (\%) & 5.41 & 4.46 & 2.86 \\
\hline Standard deviation $(\%)$ & 5.86 & 6.26 & 7.80 \\
\hline \multicolumn{4}{|l|}{ Correlation with growth rate of: } \\
\hline Service consumption & .18 & .05 & .52 \\
\hline Nondurable consumption & .07 & -.03 & .59 \\
\hline \multirow[t]{2}{*}{ Durable expenditure } & -.05 & -.20 & .72 \\
\hline & \multicolumn{3}{|c|}{ B. Operating Income Growth } \\
\hline Mean (\%) & 5.46 & 4.63 & 2.77 \\
\hline Standard deviation (\%) & 5.59 & 5.98 & 12.11 \\
\hline \multicolumn{4}{|c|}{ Correlation with growth rate of: } \\
\hline Service consumption & .15 & .30 & .45 \\
\hline Nondurable consumption & .18 & .22 & .57 \\
\hline Durable expenditure & .19 & .11 & .75 \\
\hline
\end{tabular}

The fundamental economic mechanism in this paper is that durablegood producers have demand that is more cyclical than that of nondurable-good producers. Table 2 provides strong empirical support for this mechanism, consistent with previous findings by Petersen and Strongin (1996). In the Census of Manufactures for the period 1958-86, they find that durable-good manufacturers are three times more cyclical than nondurable-good manufacturers, as measured by the elasticity of output (i.e., value added) with respect to gross national product. Moreover, they find that this difference in cyclicality is driven by demand instead of factors that affect supply (e.g., factor intensities, industry concentration, and unionization).

Table 3 shows that our findings for sales and operating income extend to dividends. The dividends of durable-good producers are more volatile and more correlated with aggregate consumption. In the next section, we examine whether these differences in the empirical properties of cash flows lead to differences in their stock returns.

\section{E. Stock Returns}

Table 4 reports descriptive statistics for excess returns, over the 3-month Treasury bill, on the five industry portfolios. In the 1927-2007 sample period, both the average and the standard deviation of excess returns rise in the durability of output. Excess returns on the service portfolio have a mean of 6.11 percent and a standard deviation of 18.46 percent. 
TABLE 3

Dividend Growth for the Industry Portfolios

\begin{tabular}{|c|c|c|c|}
\hline Statistic & Services & Nondurables & Durables \\
\hline & \multicolumn{3}{|c|}{ A. 1930-2007 Sample Period } \\
\hline Mean (\%) & .18 & 3.65 & 2.23 \\
\hline Standard deviation (\%) & 13.51 & 13.12 & 25.45 \\
\hline \multicolumn{4}{|l|}{ Correlation with growth rate of: } \\
\hline Service consumption & -.12 & -.04 & .15 \\
\hline Nondurable consumption & -.10 & -.04 & .19 \\
\hline Durable expenditure & -.22 & .03 & .23 \\
\hline \multicolumn{4}{|c|}{ Correlation with 2-year growth rate of: } \\
\hline Service consumption & .09 & .07 & .24 \\
\hline Nondurable consumption & .12 & .06 & .32 \\
\hline \multirow[t]{2}{*}{ Durable expenditure } & .00 & .14 & .30 \\
\hline & \multicolumn{3}{|c|}{ B. 1951-2007 Sample Period } \\
\hline Mean (\%) & 1.08 & 4.05 & 1.59 \\
\hline Standard deviation $(\%)$ & 12.48 & 12.61 & 22.32 \\
\hline \multicolumn{4}{|l|}{ Correlation with growth rate of: } \\
\hline Service consumption & -.07 & .01 & .17 \\
\hline Nondurable consumption & .04 & .06 & .21 \\
\hline Durable expenditure & -.17 & -.07 & .23 \\
\hline \multicolumn{4}{|c|}{ Correlation with 2-year growth rate of: } \\
\hline Service consumption & .11 & .04 & .27 \\
\hline Nondurable consumption & .21 & .19 & .34 \\
\hline Durable expenditure & .04 & .11 & .37 \\
\hline
\end{tabular}

TABLE 4

Excess Returns on the Industry Portfolios

\begin{tabular}{lcccccc}
\hline \hline $\begin{array}{l}\text { Sample } \\
\text { Period }\end{array}$ & Services & Nondurables & Durables & Investment & Other & $\begin{array}{c}\text { Durables- } \\
\text { Services }\end{array}$ \\
\hline & \multicolumn{7}{c}{ A. Average Excess Returns $(\%)$} \\
\cline { 2 - 7 } $1927-2007$ & 6.11 & 8.81 & 10.30 & 8.75 & 8.43 & 4.19 \\
& $(2.05)$ & $(2.06)$ & $(3.15)$ & $(3.14)$ & $(2.49)$ & $(2.08)$ \\
$1927-50$ & 6.34 & 9.22 & 14.15 & 12.38 & 10.90 & 7.81 \\
& $(4.77)$ & $(4.77)$ & $(8.10)$ & $(7.62)$ & $(5.88)$ & $(5.50)$ \\
$1951-2007$ & 6.01 & 8.63 & 8.67 & 7.22 & 7.39 & 2.66 \\
& $(2.14)$ & $(2.16)$ & $(2.95)$ & $(3.15)$ & $(2.56)$ & $(1.84)$ \\
\cline { 2 - 7 } & \multicolumn{7}{c}{ B. Standard Deviation of Excess Returns (\%) } \\
$1927-2007$ & 18.46 & 18.51 & 28.38 & 28.30 & 22.43 & 18.69 \\
$1927-50$ & 23.38 & 23.35 & 39.66 & 37.33 & 28.79 & 26.96 \\
$1951-2007$ & 16.19 & 16.29 & 22.25 & 23.75 & 19.36 & 13.88 \\
\hline
\end{tabular}

NotE.-We define five industries on the basis of their primary contribution to final demand according to the benchmark input-output accounts. We then sort the universe of NYSE, AMEX, and Nasdaq stocks into five industry portfolios on the basis of their SIC codes. The table reports the mean and the standard deviation of annual excess returns over the 3-month T-bill. Standard errors are reported in parentheses. 
Excess returns on the nondurable-good portfolio have a mean of 8.81 percent and a standard deviation of 18.51 percent. Finally, excess returns on the durable-good portfolio have a mean of 10.30 percent and a standard deviation of 28.38 percent. The spread in average returns between the durable-good portfolio and the service portfolio, reported in the last column, is 4.19 percent with a standard error of 2.08 percent.

The spread in average returns between the durable-good portfolio and the service portfolio is larger prior to 1951. In unreported analysis, we tabulate excess returns on the industry portfolios in 10-year subsamples. The durable-good portfolio has higher average returns than both the service portfolio and the nondurable-good portfolio in every decade, with the exception of 1957-66 and 1977-86. Interestingly, the largest spread in average returns occurred in the 1927-36 period, during the Great Depression. The spread between the durable-good portfolio and the nondurable-good portfolio is almost 11 percent, and the spread between the durable-good portfolio and the service portfolio is almost 14 percent. In the next section, we provide more formal evidence for time-varying expected returns that is related to the business cycle.

\section{F. $\quad$ Predictability of Stock Returns}

In this subsection, we examine whether expected returns on the industry portfolios are related to the strength of demand for durable goods over the business cycle. Our key forecasting variable is the ratio of net durable expenditure to the stock of durables, which we refer to as the durable expenditure-stock ratio. As shown in figure 2, the durable expenditurestock ratio is strongly procyclical, peaking during business cycle expansions.

Panel A of table 5 reports evidence for the predictability of excess returns on the industry portfolios. We report results for both the full sample, 1927-2007, and the postwar sample, 1951-2007. The postwar sample is often used in empirical work because of the possibility of nonstationarity in durable expenditure during and immediately after the war (e.g., Ogaki and Reinhart 1998; Yogo 2006). We focus our discussion on the postwar sample because the results are qualitatively similar for the full sample.

In a univariate regression, the durable expenditure-stock ratio predicts excess returns on the service portfolio with a coefficient of -3.52 , the nondurable-good portfolio with a coefficient of -0.15 , and the durable-good portfolio with a coefficient of -5.38 . The negative coefficient across the portfolios implies that the durable expenditure-stock ratio predicts the common countercyclical component of expected stock returns. This finding is similar to a previous finding that the ratio of investment to the capital stock predicts aggregate stock returns (Coch- 


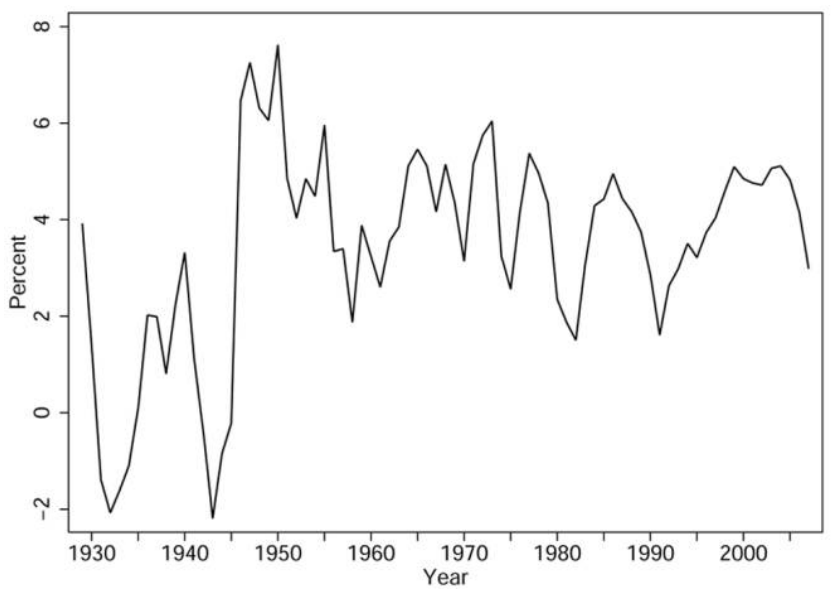

Fig. 2.-Ratio of net durable expenditure to the stock of durables. The stock of durables is the sum of the stock of consumer durable goods and the stock of private residential fixed assets. The sample period is 1929-2007.

rane 1991). Of more interest than the common sign is the relative magnitude of the coefficient across the portfolios. The durable-good portfolio has the largest coefficient, implying that it has the largest amount of countercyclical variation in expected stock returns. More formally, the last column of table 5 shows that excess returns on the durable-good portfolio over the market portfolio are predictable with a statistically significant coefficient of -3.41 .

In order to further assess the evidence for return predictability, table 5 also examines a bivariate regression that includes each portfolio's own dividend yield. The dividend yield predicts excess returns with a positive coefficient as expected and adds predictive power over the durable expenditure-stock ratio in the sense of $R^{2}$. However, the coefficient for the durable expenditure-stock ratio is hardly changed from the univariate regression.

In a model of risk and return, the returns on the industry portfolios should be predictable only if their conditional risk is also predictable. Table 6 reports reduced-form regressions of the absolute value of excess returns onto the lagged forecasting variables. (See Sec. V for a structural estimation of risk and return.) In a univariate regression, the durable expenditure-stock ratio predicts the absolute value of excess returns on the service portfolio with a coefficient of 0.39 , the nondurable-good portfolio with a coefficient of 1.39 , and the durable-good portfolio with a coefficient of -1.41 . While these coefficients are not statistically significant in the postwar sample, the empirical pattern suggests that the 


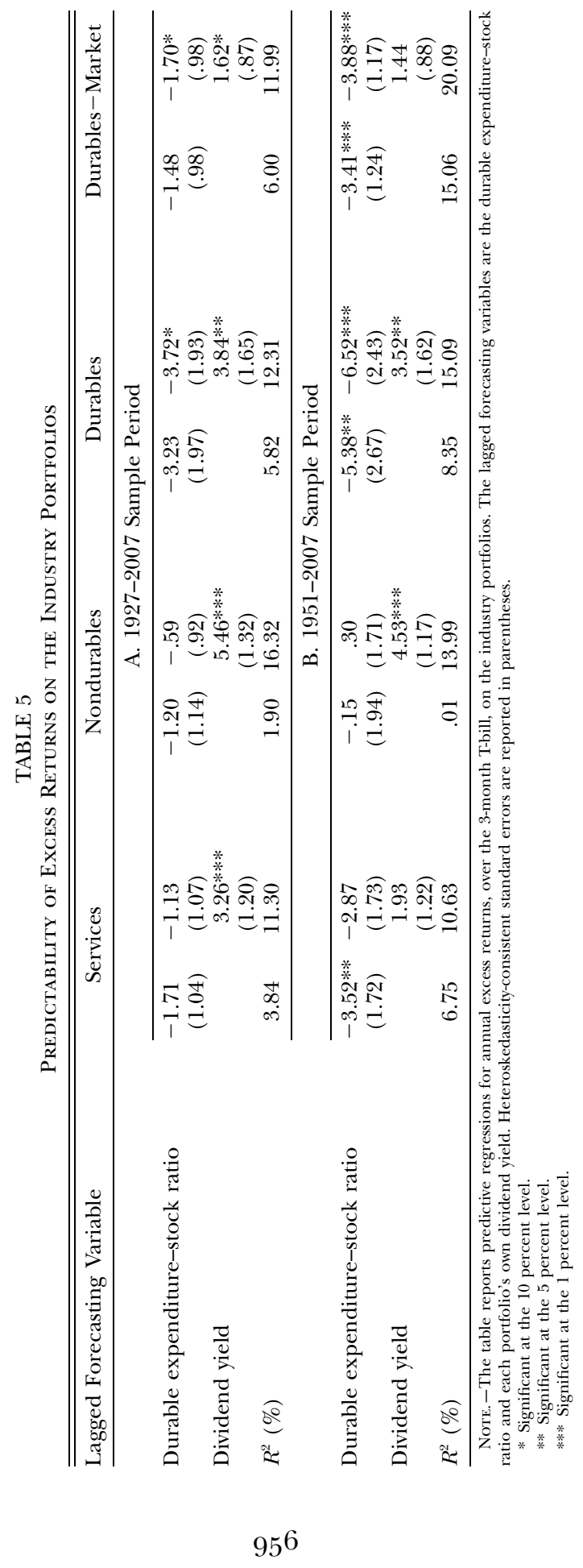




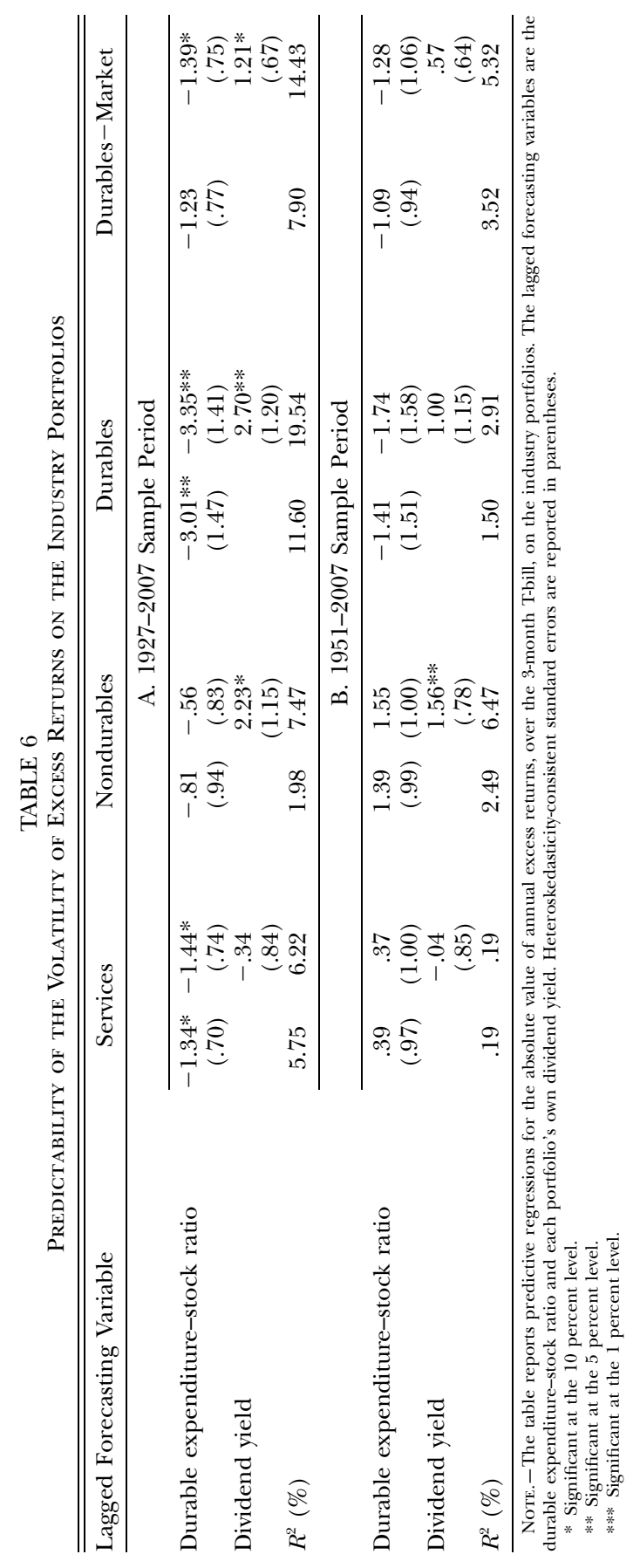

957 
TABLE 7

Predictability of the Volatility of Cash Flow Growth for the Industry PortFolios

\begin{tabular}{|c|c|c|c|c|c|c|}
\hline $\begin{array}{l}\text { Lagged } \\
\text { Forecasting } \\
\text { Variable }\end{array}$ & \multicolumn{2}{|c|}{ Services } & \multicolumn{2}{|c|}{ Nondurables } & \multicolumn{2}{|c|}{ Durables } \\
\hline & \multicolumn{6}{|c|}{ A. Sales Growth } \\
\hline $\begin{array}{l}\text { Durable expendi- } \\
\text { ture-stock ratio }\end{array}$ & $\begin{array}{l}1.16 * * * \\
(.38)\end{array}$ & $\begin{array}{l}.82 * * \\
(.31)\end{array}$ & $\begin{array}{l}1.61 * * * \\
(.60)\end{array}$ & $\begin{array}{l}1.59 * * * \\
(.58)\end{array}$ & $\begin{array}{c}-.97 * * \\
(.42)\end{array}$ & $\begin{array}{c}-1.10^{* *} \\
(.46)\end{array}$ \\
\hline Dividend yield & & $\begin{array}{c}-1.02 * * \\
(.42)\end{array}$ & & $\begin{array}{r}-.18 \\
(.49)\end{array}$ & & $\begin{array}{l}.39 \\
(.36)\end{array}$ \\
\hline \multirow[t]{2}{*}{$R^{2}(\%)$} & 9.15 & 22.65 & 17.54 & 17.81 & 5.65 & 7.32 \\
\hline & \multicolumn{6}{|c|}{ B. Operating Income Growth } \\
\hline $\begin{array}{l}\text { Durable expendi- } \\
\text { ture-stock ratio }\end{array}$ & $\begin{array}{l}.71 \\
(.62)\end{array}$ & $\begin{array}{l}.60 \\
(.69)\end{array}$ & $\begin{array}{l}1.81 * * * \\
(.32)\end{array}$ & $\begin{array}{l}1.79 * * * \\
(.31)\end{array}$ & $\begin{array}{r}-1.17 \\
(.81)\end{array}$ & $\begin{array}{r}-1.43 \\
(.87)\end{array}$ \\
\hline Dividend yield & & $\begin{array}{c}-.32 \\
(.33)\end{array}$ & & $\begin{array}{c}-.19 \\
(.34)\end{array}$ & & $\begin{array}{c}.80 \\
(.74)\end{array}$ \\
\hline \multirow[t]{2}{*}{$R^{2}(\%)$} & 3.31 & 4.61 & 26.77 & 27.17 & 3.34 & 6.23 \\
\hline & \multicolumn{6}{|c|}{ C. 5-Year Dividend Growth } \\
\hline $\begin{array}{l}\text { Durable expendi- } \\
\text { ture-stock ratio }\end{array}$ & $\begin{array}{c}1.53 \\
(1.61)\end{array}$ & $\begin{array}{c}.17 \\
(1.38)\end{array}$ & $\begin{array}{c}-4.55^{* *} \\
(1.71)\end{array}$ & $\begin{array}{c}-4.47 * * \\
(1.68)\end{array}$ & $\begin{array}{c}-10.01 * * * \\
(2.36)\end{array}$ & $\begin{array}{l}-9.94 * * * \\
(2.46)\end{array}$ \\
\hline Dividend yield & & $\begin{array}{c}-4.61 * * * \\
(1.69)\end{array}$ & & $\begin{array}{c}.86 \\
(1.31)\end{array}$ & & $\begin{array}{l}-.18 \\
(2.69)\end{array}$ \\
\hline$R^{2}(\%)$ & .85 & 15.62 & 11.17 & 11.68 & 21.52 & 21.53 \\
\hline
\end{tabular}

volatility of returns for the durable-good portfolio is more countercyclical than that for the service portfolio or the nondurable-good portfolio.

\section{G. Predictability of Cash Flow Volatility}

Differences in the conditional risk of the industry portfolios are difficult to isolate solely on the basis of stock returns. The reason is that stock returns can be driven by both aggregate news about discount rates and industry-specific news about cash flows. In table 7, we therefore examine direct evidence for the predictability of cash flow volatility. We use the same forecasting variables as those used for predicting stock returns in table 5 .

As reported in panel A, the durable expenditure-stock ratio predicts the absolute value of sales growth for service producers with a coefficient 
of 1.16, nondurable-good producers with a coefficient of 1.61, and durable-good producers with a coefficient of -0.97 . This empirical pattern suggests that the volatility of cash flow growth for durable-good producers is more countercyclical than that for service producers and nondurable-good producers. This evidence is robust to including the portfolio's own dividend yield as an additional regressor. Panel B shows that this evidence is also robust to using operating income instead of sales as the measure of cash flows.

In panel C, we examine evidence for the predictability of the volatility of 5-year dividend growth. We motivate 5-year dividend growth as a way to empirically implement the cash flow news component of a standard return decomposition (Campbell 1991). The durable expenditure-stock ratio predicts the absolute value of dividend growth for service producers with a coefficient of 1.53 , nondurable-good producers with a coefficient of -4.55 , and durable-good producers with a coefficient of -10.01 . This evidence suggests that the cash flows of durable-good producers are exposed to higher risk than those of service producers and nondurable-good producers during recessions, when durable expenditure is low relative to the stock of durables.

\section{General Equilibrium Asset-Pricing Model}

In the last section, we established two key facts about the cash flows and stock returns of durable-good producers in comparison to those of service producers and nondurable-good producers. First, the cash flows of durable-good producers are more volatile and more correlated with aggregate consumption. This unconditional cash flow risk can be a mechanism that explains why durable-good producers have higher average stock returns than nondurable-good producers. Second, the cash flows of durable-good producers are more volatile when the durable expenditure-stock ratio is low. This conditional cash flow risk can be a mechanism that explains why durable-good producers have expected stock returns that are more time varying than those of nondurable-good producers.

In this section, we develop a general equilibrium asset-pricing model as a framework to organize our empirical findings. Our work builds on the representative-household model of Dunn and Singleton (1986), Eichenbaum and Hansen (1990), Yogo (2006), and Piazzesi, Schneider, and Tuzel (2007). We endogenize the production of nondurable and durable consumption goods in a two-sector economy (see Baxter 1996). Our analysis highlights the role of durability as an economic mechanism that generates differences in firm output and cash flow risk, abstracting from other sources of heterogeneity. The model delivers most of our key empirical findings in a simple and parsimonious setting. It also 
provides the necessary theoretical structure to guide our formal econometric tests in Section V.

\section{A. Representative Household}

There is an infinitely lived representative household in an economy with a complete set of financial markets. In each period $t$, the household purchases $C_{t}$ units of a nondurable consumption good and $E_{t}$ units of a durable consumption good. The nondurable good is taken to be the numeraire, so that $P_{t}$ denotes the price of the durable good in units of the nondurable good. The nondurable good is entirely consumed in the period of purchase, whereas the durable good provides service flows for more than one period. The household's stock of the durable good $D_{t}$ is related to its expenditure by the law of motion

$$
D_{t}=(1-\delta) D_{t-1}+E_{t}
$$

where $\delta \in(0,1]$ is the depreciation rate.

The household's utility flow in each period is given by the constant elasticity of substitution function:

$$
u(C, D)=\left[(1-\alpha) C^{1-1 / \rho}+\alpha D^{1-1 / \rho}\right]^{1 /(1-1 / \rho)} .
$$

The parameter $\alpha \in(0,1)$ is the utility weight on the durable good, and $\rho \geq 0$ is the elasticity of substitution between the two consumption goods. Implicit in this specification is the assumption that the service flow from the durable good is a constant proportion of its stock. We therefore use the words "stock" and "consumption" interchangeably in reference to the durable good.

The household maximizes expected discounted utility, defined by the recursive objective function (Weil 1990; Epstein and Zin 1991):

$$
U_{t}=\left\{(1-\beta) u\left(C_{t}, D_{t}\right)^{1-1 / \sigma}+\beta \mathbf{E}_{t}\left[U_{t+1}^{1-\gamma}\right]^{1 / \kappa}\right\}^{1 /(1-1 / \sigma)} .
$$

The parameter $\beta \in(0,1)$ is the household's subjective discount factor. The parameter $\sigma \geq 0$ is its elasticity of intertemporal substitution, and $\gamma>0$ is its relative risk aversion. We define $\kappa=(1-\gamma) /(1-1 / \sigma)$ to simplify notation.

\section{B. Firms and Production}

The economy consists of two productive sectors, one that produces nondurable goods (including services) and another that produces durable goods. For simplicity, we do not model a third sector that produces investment goods (see Papanikolaou 2008). Each sector consists of a representative firm that takes input and output prices as given. Each 
firm produces output using a common variable factor of production and a sector-specific fixed factor of production.

\section{Aggregate Productivity}

Aggregate productivity evolves as a geometric random walk with timevarying drift. Specifically, we assume that aggregate productivity in period $t$ is given by

$$
\begin{gathered}
X_{t}=X_{t-1} \exp \left\{\mu+z_{t}+e_{t}\right\}, \\
z_{t}=\phi z_{t-1}+v_{t},
\end{gathered}
$$

where $e_{t} \sim \mathbf{N}\left(0, \sigma_{e}^{2}\right)$ and $v_{t} \sim \mathbf{N}\left(0, \sigma_{v}^{2}\right)$ are independently and identically distributed shocks. The variable $z_{t}$ captures the persistent (business cycle) component of aggregate productivity, which evolves as a firstorder autoregression.

\section{Firm Producing Nondurable Goods}

In each period $t$, the nondurable-good firm rents $L_{C t}$ units of a variable input at the rental rate $W_{t}$ and $K_{C t}$ units of a fixed input at the rental rate $W_{C}$. This latter input is fixed in the sense that the input is productive only in the nondurable-good sector and is productive with a one-period lag. Let $Y_{C t}$ denote production and $C_{t}$ denote sales by the nondurablegood firm in period $t$. The nondurable-good firm has the production function

$$
Y_{C t}=\left[\left(X_{t} L_{C t}\right)^{\theta_{C}} K_{C, t-1}^{1-\theta_{C}}\right]^{\eta},
$$

where $\theta_{C} \in(0,1)$ is the elasticity of output with respect to the variable input. The parameter $\eta \in(0,1]$ determines the returns to scale. The production of the nondurable good must equal its sales in each period because it cannot be inventoried (i.e., $Y_{C t}=C_{t}$ ).

Define the cash flow of the nondurable-good firm in period $t$ as

$$
\Pi_{C t}=C_{t}-W_{t} L_{C t}-W_{C t} K_{C t} .
$$

Let $M_{t}$ be the stochastic discount factor used to discount any cash flow in period $t$. The value of the firm is the present discounted value of its future cash flows, that is,

$$
V_{C t}=\mathbf{E}_{t}\left[\sum_{s=1}^{\infty} \prod_{r=1}^{s} M_{t+r} \Pi_{C, t+s}\right] .
$$

The gross return on a claim to the cash flows of the nondurable-good firm is 


$$
R_{C, t+1}=\frac{V_{C, t+1}+\Pi_{C, t+1}}{V_{C t}} .
$$

In each period $t$, the nondurable-good firm chooses the quantity of its inputs $L_{C t}$ and $K_{C t}$ to maximize its value, $\Pi_{C t}+V_{C t}$.

\section{Firm Producing Durable Goods}

A key economic property of durable goods is that they can be inventoried, unlike nondurable goods and services. The durable-good firm's inventory of finished goods evolves according to the law of motion

$$
D_{I t}=(1-\delta) D_{I, t-1}+E_{I t},
$$

where $E_{I t}$ is the investment in inventory. Inventory investment can be negative whenever the firm sells finished goods from its inventory.

In each period $t$, the durable-good firm rents $L_{E t}$ units of a variable input at the rental rate $W_{t}$ and $K_{E t}$ units of a fixed input at the rental rate $W_{E t}$. This latter input is fixed in the sense that the input is productive only in the durable-good sector and is productive with a one-period lag. Let $Y_{E t}$ denote production and $E_{t}$ denote sales by the durable-good firm in period $t$. The durable-good firm has the production function

$$
Y_{E t}=\left[\left(X_{t} L_{E t}\right)^{\theta_{E}} K_{E, t-1}^{1-\theta_{E}-\theta_{I}} D_{I, t-1}^{\theta_{I}}\right]^{\eta},
$$

where $\theta_{E} \in(0,1)$ is the elasticity of output with respect to the variable input.

The firm keeps an inventory because it is a factor of production, following a modeling convention in macroeconomics (e.g., Kydland and Prescott 1982). Because the inventory is that of finished goods, our motivation is similar to that of Bils and Kahn (2000), in which an inventory of finished goods is necessary to generate sales (e.g., cars in the showroom). We assume that changes in the inventory incur adjustment costs, which introduces a realistic friction between the household sector and the durable-good firm. In each period, the production of the durable good must equal the sum of sales, inventory investment, and adjustment costs:

$$
Y_{E t}=E_{t}+E_{I t}+\frac{\tau\left(D_{I t}-D_{I, t-1}\right)^{2}}{2 D_{I, t-1}}
$$

where $\tau \geq 0$ determines the degree of adjustment costs.

Define the cash flow of the durable-good firm in period $t$ as

$$
\Pi_{E t}=P_{t} E_{t}-W_{t} L_{E t}-W_{E t} K_{E t} .
$$

The value of the firm is the present discounted value of its future cash 
flows, that is,

$$
V_{E t}=\mathbf{E}_{t}\left[\sum_{s=1}^{\infty} \prod_{r=1}^{s} M_{t+r} \Pi_{E, t+s}\right] .
$$

The gross return on a claim to the cash flows of the durable-good firm is

$$
R_{E, t+1}=\frac{V_{E, t+1}+\Pi_{E, t+1}}{V_{E t}} .
$$

In each period $t$, the durable-good firm chooses the quantity of its inputs $L_{E t}$ and $K_{E t}$ to maximize its value, $\Pi_{E t}+V_{E t}$.

\section{Competitive Equilibrium}

\section{Household's First-Order Conditions}

The household's consumption and portfolio choice problem is the same as that in an endowment economy. We therefore state the first-order conditions here without derivation and refer the reader to Yogo (2006, app. B) for a complete derivation.

The sum of equations (7) and (13) implies the household's aggregate budget constraint:

$$
C_{t}+P_{t} E_{t}=W_{t}\left(L_{C t}+L_{E t}\right)+W_{C t} K_{C t}+W_{E t} K_{E t}+\Pi_{C t}+\Pi_{E t} .
$$

In words, consumption expenditures must equal the sum of rental and capital income. Let $V_{M t}$ be the present discounted value of future consumption expenditures, that is,

$$
V_{M t}=\mathbf{E}_{t}\left[\sum_{s=1}^{\infty} \prod_{r=1}^{s} M_{t+r}\left(C_{t+s}+P_{t+s} E_{t+s}\right)\right] .
$$

The gross return on a claim to the household's consumption expenditures (equivalently, rental and capital income) is

$$
R_{M, t+1}=\frac{V_{M, t+1}+C_{t+1}+P_{t+1} E_{t+1}}{V_{M t}} .
$$

The household's wealth consists of the stock of durables and the present discounted value of future rental and capital income. Define 
the gross return on aggregate wealth as

$$
R_{W, t+1}=\left(1-\frac{Q_{t} D_{t}}{V_{M t}+P_{t} D_{t}}\right)^{-1}\left\{R_{M, t+1}+\frac{P_{t} D_{t}}{V_{M t}+P_{t} D_{t}}\left[\frac{(1-\delta) P_{t+1}}{P_{t}}-R_{M, t+1}\right]\right\}
$$

In words, the return on wealth is a weighted average of returns on durable goods and the claim to the household's consumption expenditures. If the durable good were to fully depreciate each period (i.e., $\delta=1$ ), aggregate wealth would simply be the present value of future consumption expenditures (i.e., $R_{W t}=R_{M t}$ ).

Define the user cost of the service flow from the durable good as

$$
Q_{t}=P_{t}-(1-\delta) \mathbf{E}_{t}\left[M_{t+1} P_{t+1}\right] .
$$

In words, the user cost is equal to the purchase price today minus the present discounted value of the depreciated stock tomorrow. The household's first-order conditions imply that

$$
Q_{t}=\frac{\alpha}{1-\alpha}\left(\frac{D_{t}}{C_{t}}\right)^{-1 / \rho}
$$

Intuitively, the user cost for the durable good must equal the marginal rate of substitution between the durable good and the nondurable good.

Define the household's intertemporal marginal rate of substitution, or the stochastic discount factor, as

$$
M_{t+1}=\left\{\beta\left(\frac{C_{t+1}}{C_{t}}\right)^{-1 / \sigma}\left[\frac{v\left(D_{t+1} / C_{t+1}\right)}{v\left(D_{t} / C_{t}\right)}\right]^{1 / \rho-1 / \sigma} \quad R_{W, t+1}^{1-1 / \kappa}\right\}^{\kappa},
$$

where

$$
v\left(\frac{D}{C}\right)=\left[1-\alpha+\alpha\left(\frac{D}{C}\right)^{1-1 / \rho}\right]^{1 /(1-1 / \rho)} .
$$

As is well known, the absence of arbitrage implies that gross asset returns satisfy

$$
\mathbf{E}_{t}\left[M_{t+1} R_{i, t+1}\right]=1,
$$

for all assets $i=C, E, M$. 


\section{Firms' First-Order Conditions}

The firms' first-order conditions imply that the competitive rental rate of the variable input must equal its marginal product:

$$
W_{t}=\frac{\eta \theta_{C} C_{t}}{L_{C t}}=\frac{\eta \theta_{E} P_{t} Y_{E t}}{L_{E t}} .
$$

Similarly, the rental rate of the fixed input in each sector must equal their respective marginal products:

$$
\begin{gathered}
W_{C t}=\frac{\eta\left(1-\theta_{C}\right) \mathbf{E}_{t}\left[M_{t+1} C_{t+1}\right]}{K_{C t}}, \\
W_{E t}=\frac{\eta\left(1-\theta_{E}-\theta_{t}\right) \mathbf{E}_{t}\left[M_{t+1} P_{t+1} Y_{E, t+1}\right]}{K_{E t}} .
\end{gathered}
$$

Finally, the optimal level of inventory held by the durable-good firm is determined by the first-order condition

$$
\begin{aligned}
Q_{t}= & \frac{\eta \theta_{I} \mathbf{E}_{t}\left[M_{t+1} P_{t+1} Y_{E, t+1}\right]}{D_{I t}}-\tau P_{t}\left(\frac{D_{I t}}{D_{I, t-1}}-1\right) \\
& +\frac{\tau}{2} \mathbf{E}_{t}\left[M_{t+1} P_{t+1}\left[\left(\frac{D_{I, t+1}}{D_{I t}}\right)^{2}-1\right]\right] .
\end{aligned}
$$

In words, the user cost of the durable good must equal the marginal product of inventory.

\section{Market Clearing}

In each period, the household inelastically supplies the variable input and the sector-specific fixed inputs, which we normalize to one unit each. Market clearing in the input markets requires that

$$
\begin{gathered}
1=L_{C t}+L_{E t}, \\
1=K_{C t}=K_{E t} .
\end{gathered}
$$

The goods markets also clear. In each period, the sales of the nondurable-good firm are equal to the household's nondurable consumption. The sales of the durable-good firm are equal to the household's durable expenditure. 
TABLE 8

Parameters Used in the Calibrated Model

\begin{tabular}{lcc}
\hline \hline Parameter & Symbol & Value \\
\hline Depreciation rate of durable good & $\delta$ & $4.63 \%$ \\
Preferences: & & .98 \\
Discount factor & $\sigma$ & 2 \\
Elasticity of intertemporal subsitution & $\gamma$ & 10 \\
Relative risk aversion & $\rho$ & .60 \\
Elasticity of subsitution between goods & $\alpha$ & .50 \\
Utility weight on durable good & & \\
Technology: & $\mu$ & $1.78 \%$ \\
Growth rate & $\sigma_{e}$ & \\
Standard deviation of i.i.d. component & & $.71 \%$ \\
Standard deviation of shock to persistent & $\sigma_{v}$ & $.05 \%$ \\
$\quad$ component & $\phi$ & .90 \\
Autocorrelation of persistent component & & .80 \\
Production: & $\eta$ & .72 \\
Returns to scale & $\theta_{C}$ & .11 \\
Nondurable firm's elasticity for variable input & $\theta_{E}$ & 3 \\
Durable firm's elasticity for variable input & $\theta_{I}$ & $\tau$ \\
Durable firm's elasticity for inventory & $b$ & $52 \%$ \\
Adjustment cost for inventory & $b^{\prime}$ & \\
Financial leverage & &
\end{tabular}

\section{Asset-Pricing Implications of the Production Economy}

\section{A. Calibration of the Model}

Table 8 reports the parameters that we use for our calibration. We set the depreciation rate to 4.63 percent, which is the average annual depreciation rate for the sum of consumer durable goods and private residential fixed assets.

We must restrict household preferences and the firms' production parameters in order to obtain stationary dynamics, or prices and quantities that are cointegrated with the appropriate power of aggregate productivity. ${ }^{3}$ We restrict the production parameters so that all the quantities in the economy are cointegrated with $X_{t}^{\chi}$, where

$$
\chi=\eta \theta_{C}=\frac{\eta \theta_{E}}{1-\eta \theta_{I}} .
$$

Our choices for the production parameters are otherwise dictated by

\footnotetext{
${ }^{3}$ The Epstein-Zin objective function restricts preferences to be homothetic, which is necessary for stationary dynamics in the model. Homothetic preferences suffice for our analysis because the volatility of nondurable and service consumption is similar to that of the stock of durables (i.e., the sum of consumer durable goods and private residential fixed assets) at our level of aggregation. Bils and Klenow (1998) and Pakoš (2004) analyze a model with nonhomothetic preferences for more disaggregated categories of consumption, where the evidence for nonhomotheticity seems stronger.
} 
standard choices in macroeconomics. We set the degree of returns to scale to $\eta=0.9$ (see Burnside, Eichenbaum, and Rebelo 1995; Basu and Fernald 1997). For the purposes of calibration, we view the variable input as inputs such as labor and the flexible part of capital. We view the fixed input as inputs such as land and the inflexible part of capital. For the nondurable-good firm, we set the elasticity of output with respect to the variable input to $\theta_{C}=0.8$.

Table 9 reports the empirical moments for the macroeconomic variables in panel $\mathrm{A}$, operating income growth in panel $\mathrm{B}$, and stock returns in panel C. We report the empirical moments for two sample periods, 1930-2007 and 1951-2007. (Macroeconomic data from the National Income and Product Accounts are not available prior to 1929, and cash flow data from Compustat are not available prior to 1950.) Both nondurable and service consumption and durable expenditure are somewhat more volatile in the longer sample, but otherwise, the empirical moments are quite similar across the two samples. We calibrate our model to the longer sample because the higher volatility of the macroeconomic variables in this sample makes the task of explaining asset prices somewhat easier.

We solve the model by numerical dynamic programming as detailed in Appendix C. We simulate the model at an annual frequency for 500,000 years to compute the population moments reported in table 9. We compare the cash flows and stock returns of the nondurablegood firm in the model to those of the service (instead of the nondurable-good) portfolio in the data in order to set a higher hurdle for the model.

\section{B. Implications for Aggregate Consumption}

Panel A of table 9 lists the macroeconomic variables that we target in our calibration:

- $\log \left(C_{t} / C_{t-1}\right)$, the log growth rate of real nondurable and service consumption;

- $\log \left(E_{t} / E_{t-1}\right)$, the $\log$ growth rate of real durable expenditure;

- $P_{t} E_{t} / C_{t}$, the ratio of durable expenditure to nondurable and service consumption;

- $\left(D_{t}-D_{t-1}\right) / D_{t}$, the ratio of net durable expenditure to the stock of durables;

- $D_{I t} / E_{t}$, the ratio of inventory to sales for durable goods.

By matching the first two moments and the autocorrelation for these variables, we ensure realistic implications for aggregate consumption and the relative price of durable goods. In order to assess the cyclical properties of these variables, table 9 also reports the contemporaneous 
TABLE 9

Comparison of Empirical Moments with Moments in the Simulated Model

\begin{tabular}{|c|c|c|c|}
\hline \multirow[b]{2}{*}{ VARIAble and Statistic } & \multicolumn{2}{|c|}{ SAMPle Period } & \multirow[b]{2}{*}{ MODEL } \\
\hline & $1930-2007$ & $1951-2007$ & \\
\hline & \multicolumn{3}{|c|}{ A. Macroeconomic Variables } \\
\hline \multicolumn{4}{|l|}{ Nondurable and service consumption growth: } \\
\hline Mean $(\%)$ & 1.96 & 2.05 & 2.00 \\
\hline Standard deviation (\%) & 2.65 & 1.16 & 2.67 \\
\hline Autocorrelation & .50 & .39 & .51 \\
\hline \multicolumn{4}{|l|}{ Durable expenditure growth: } \\
\hline Mean $(\%)$ & 2.43 & 2.26 & 2.00 \\
\hline Standard deviation (\%) & 16.93 & 8.37 & 14.79 \\
\hline Autocorrelation & .29 & .16 & -.21 \\
\hline \multicolumn{4}{|l|}{ Durable-nondurable expenditure ratio: } \\
\hline Mean $(\%)$ & 24.38 & 27.10 & 22.06 \\
\hline Standard deviation $(\%)$ & 5.97 & 2.85 & 6.85 \\
\hline Autocorrelation & .89 & .65 & .86 \\
\hline \multicolumn{4}{|l|}{ Correlation with growth rate of: } \\
\hline Nondurable and service consumption & .08 & .43 & .87 \\
\hline Durable expenditure & .24 & .38 & .39 \\
\hline \multicolumn{4}{|l|}{ Durable expenditure-stock ratio: } \\
\hline Mean $(\%)$ & 3.42 & 4.09 & 1.97 \\
\hline Standard deviation $(\%)$ & 2.14 & 1.19 & 1.72 \\
\hline Autocorrelation & .79 & .51 & .89 \\
\hline \multicolumn{4}{|l|}{ Correlation with growth rate of: } \\
\hline Nondurable and service consumption & .21 & .54 & .85 \\
\hline Durable expenditure & .49 & .58 & .34 \\
\hline \multicolumn{4}{|l|}{ Durable inventory-sales ratio: } \\
\hline Mean $(\%)$ & & 71.70 & 68.49 \\
\hline Standard deviation (\%) & & 12.69 & 14.46 \\
\hline Autocorrelation & & .83 & .70 \\
\hline \multicolumn{4}{|l|}{ Correlation with growth rate of: } \\
\hline Nondurable and service consumption & & -.13 & -.86 \\
\hline \multirow[t]{2}{*}{ Durable expenditure } & & -.36 & -.52 \\
\hline & \multicolumn{3}{|c|}{$\begin{array}{l}\text { B. Operating Income Growth/Cash } \\
\text { Flow Growth }\end{array}$} \\
\hline \multicolumn{4}{|l|}{ Market portfolio: } \\
\hline Mean $(\%)$ & & 4.99 & 2.00 \\
\hline Standard deviation (\%) & & 5.47 & 8.02 \\
\hline \multicolumn{4}{|l|}{ Correlation with growth rate of: } \\
\hline Nondurable and service consumption & & .51 & .76 \\
\hline Durable expenditure & & .49 & .87 \\
\hline \multicolumn{4}{|l|}{ Service portfolio/nondurable-good firm: } \\
\hline Mean (\%) & & 5.46 & 2.00 \\
\hline Standard deviation (\%) & & 5.59 & 2.92 \\
\hline \multicolumn{4}{|l|}{ Correlation with growth rate of } \\
\hline Nondurable and service consumption & & .12 & .95 \\
\hline Durable expenditure & & .19 & .41 \\
\hline \multicolumn{4}{|l|}{ Durable-good portfolio/durable-good firm: } \\
\hline Mean $(\%)$ & & 2.77 & 2.00 \\
\hline Standard deviation $(\%)$ & & 12.11 & 31.59 \\
\hline \multicolumn{4}{|l|}{ Correlation with growth rate of: } \\
\hline Nondurable and service consumption & & .38 & .58 \\
\hline Durable expenditure & & .75 & .92 \\
\hline
\end{tabular}


TABLE 9

(Continued)

\begin{tabular}{|c|c|c|c|}
\hline \multirow[b]{2}{*}{ VARIAble and Statistic } & \multicolumn{2}{|c|}{ SAMPLE PERIOD } & \multirow[b]{2}{*}{ ModeI } \\
\hline & 1930-2007 & $1951-2007$ & \\
\hline & \multicolumn{3}{|c|}{ C. Excess Returns } \\
\hline \multicolumn{4}{|l|}{ Market portfolio: } \\
\hline Mean $(\%)$ & 6.87 & 7.48 & 5.80 \\
\hline Standard deviation (\%) & 20.16 & 17.13 & 9.29 \\
\hline \multicolumn{4}{|l|}{ Correlation with growth rate of: } \\
\hline Nondurable and service consumption & .61 & .31 & .38 \\
\hline Durable expenditure & .49 & .38 & .77 \\
\hline \multicolumn{4}{|l|}{ Service portfolio/nondurable-good firm: } \\
\hline Mean $(\%)$ & 5.45 & 6.13 & 5.03 \\
\hline Standard deviation $(\%)$ & 18.30 & 15.62 & 8.06 \\
\hline \multicolumn{4}{|l|}{ Correlation with growth rate of: } \\
\hline Nondurable and service consumption & .49 & .22 & .39 \\
\hline Durable expenditure & .46 & .41 & .78 \\
\hline \multicolumn{4}{|l|}{ Durable-good portfolio/durable-good firm: } \\
\hline Mean $(\%)$ & 8.85 & 9.12 & 10.26 \\
\hline Standard deviation (\%) & 27.22 & 21.52 & 16.55 \\
\hline \multicolumn{4}{|l|}{ Correlation with growth rate of: } \\
\hline Nondurable and service consumption & 60 & .34 & .35 \\
\hline Durable expenditure & .49 & .57 & .77 \\
\hline \multicolumn{4}{|l|}{ T-bill rate/risk-free rate: } \\
\hline Mean $(\%)$ & 1.02 & 1.64 & 1.65 \\
\hline Standard deviation (\%) & 3.99 & 2.47 & 1.54 \\
\hline \multicolumn{4}{|l|}{ Correlation with growth rate of: } \\
\hline Nondurable and service consumption & -.67 & -.15 & .82 \\
\hline Durable expenditure & -.22 & .17 & .20 \\
\hline $\begin{array}{l}\text { Note.-Panel A reports the mean, the standard devi } \\
\text { variables in the data and the simulated model. The varia } \\
\text { consumption, the log growth rate of real durable expen } \\
\text { service consumption, the ratio of net durable expenditur } \\
\text { for durable goods. Panel B reports moments for the log } \\
\text { Panel C reports moments for real excess returns over th }\end{array}$ & $\begin{array}{l}1 \\
\text { bill (the ri }\end{array}$ & $\begin{array}{l}\text { (cash flows } \\
\text { asset in the } 1\end{array}$ & $\begin{array}{l}\text { economic } \\
\text { id service } \\
\text { rable and } \\
\text { ry to sales } \\
\text { e model). } \\
\text {. Table } 8\end{array}$ \\
\hline
\end{tabular}

correlation of each variable with nondurable and service consumption growth as well as durable expenditure growth.

Our parameter choices for aggregate productivity are dictated by the mean, the standard deviation, and the autocorrelation of nondurable and service consumption growth. We first set $\mu=2.78$ percent, which implies that the average growth rate of nondurable and service consumption is 2 percent. Following Bansal and Yaron (2004), we model productivity growth as having a persistent component with an autoregressive parameter $\phi=0.78$. We then set the standard deviation of the shocks (i.e., $\sigma_{e}$ and $\sigma_{v}$ ) so that the log growth rate of aggregate productivity has the moments

$$
\text { standard deviation }=\sqrt{\sigma_{e}^{2}+\sigma_{v}^{2} /\left(1-\phi^{2}\right)}=2.5 \%,
$$


and

$$
\text { autocorrelation }=\frac{\phi}{1+\sigma_{e}^{2}\left(1-\phi^{2}\right) / \sigma_{v}^{2}}=.7 \text {. }
$$

These choices lead to a standard deviation of 2.67 percent and autocorrelation of .51 for nondurable consumption growth in the model, which coincide with the empirical moments.

An important parameter in the calibration is the elasticity of substitution between the two consumption goods. Under the identifying assumption that the spot price and the user cost of durable goods are cointegrated, the elasticity of substitution can be identified from a dynamic ordinary least squares regression of $\log \left(C_{t} / D_{t}\right)$ onto $\log \left(P_{t}\right)$ (see Ogaki and Reinhart 1998; Yogo 2006). For the 1930-2007 sample period, we obtain an estimate of $\rho=0.57$ with a standard error of 0.06 . On the basis of this estimate, we set $\rho=0.6$ in the calibration. We then set $\alpha=0.5$ to match the average ratio of durable expenditure to nondurable and service consumption. The durable-nondurable expenditure ratio is procyclical in both the data and the model; it has a positive contemporaneous correlation with both nondurable and service consumption growth and durable expenditure growth.

We do not have any free parameters to match the moments for durable expenditure growth and the durable expenditure-stock ratio. Nevertheless, the model is fairly successful at matching the moments for these variables. The standard deviation of durable expenditure growth is 14.79 percent in the model, which comes close to its empirical target of 16.93 percent.

The ratio of inventory to sales for durable goods is pinned down by the inventory elasticity of output $\theta_{I}$ and the degree of adjustment costs for inventory $\tau$. We set $\theta_{I}=0.11$ to match the average inventory-sales ratio. The restriction on the production parameters then requires that $\theta_{E}=\theta_{C}\left(1-\eta \theta_{I}\right)=0.72$. We set $\tau=3$ to roughly match the standard deviation of the inventory-sales ratio, which is 12.69 percent in the data. The inventory-sales ratio is countercyclical in both the data and the model; it has a negative contemporaneous correlation with both nondurable and service consumption growth and durable expenditure growth.

\section{Implications for Cash Flows}

One of the key facts established in Section II is that durable-good producers have cash flows that are more volatile and cyclical than those of service producers and nondurable-good producers. The model must match this fact in order to have successful implications for the firms' 
stock returns. Panel B of table 9 reports the mean and the standard deviation of operating income growth in the data as well as cash flow growth in the model.

The standard deviation of cash flow growth for the nondurable-good firm in the model is 2.92 percent, which is slightly higher than the standard deviation of nondurable consumption growth. This effect is a consequence of the sector-specific fixed input, which generates operating leverage and makes cash flows more volatile than sales.

The standard deviation of cash flow growth for the durable-good firm is 31.59 percent, which is significantly higher than 14.79 percent for the standard deviation of durable expenditure growth. The correlation between cash flows and durable expenditure is higher than that between cash flows and nondurable consumption in both the data and the model. The cash flows of the durable-good firm are very volatile in the model because the existence of inventory allows the firm to disconnect production from sales. Intuitively, the household has preferences for smooth consumption, which the durable-good firm can support with very cyclical production smoothed by changes in inventory.

\section{Implications for Asset Returns}

We compute the one-period risk-free interest rate in the model as

$$
R_{f t}=\frac{1}{\mathbf{E}_{t-1}\left[M_{t}\right]} .
$$

In order to compare firm returns in the model to stock returns in the data, we must first introduce financial leverage. Equity is a levered claim on the firm's cash flows. Consider a portfolio that is long $V_{i t}$ dollars in firm $i$ and short $b V_{i t}$ dollars in the risk-free asset. The one-period return on the levered strategy is

$$
\tilde{R}_{i t}=\frac{1}{1-b} R_{i t}-\frac{b}{1-b} R_{f t}
$$

We compute stock returns in the model through this formula, using an empirically estimated value for market leverage. We compute the market leverage for all Compustat firms as the ratio of the book value of liabilities to the market value of assets (i.e., the sum of book liabilities and market equity). While the market leverage varies over time, it is on average 52 percent in the postwar sample. We therefore set $b=52$ percent in the calibration.

As is well known, it is difficult to generate a high equity premium and high volatility of stock returns in a general equilibrium model, especially in models with production. Following Bansal and Yaron 
(2004), we combine the persistence of productivity growth and an elasticity of intertemporal substitution greater than one so that asset prices rise in response to a positive productivity shock. Specifically, we choose a fairly high elasticity of intertemporal substitution of $\sigma=2$, which magnifies the volatility of stock returns while keeping the volatility of the risk-free rate low. To generate a nontrivial equity premium, we choose a fairly high risk aversion of $\gamma=10$.

Panel C of table 9 reports the first two moments of stock returns implied by the model. The nondurable-good firm has excess returns, over the risk-free asset, with a mean of 5.03 percent and a standard deviation of 8.06 percent. The durable-good firm has excess returns with a mean of 10.26 percent and a standard deviation of 16.55 percent. The spread in average stock returns between the two firms exceeds 5 percent, which compares favorably with the empirical evidence. However, the spread in the volatility of returns is somewhat lower than the empirical target because our model is not designed to resolve the equity volatility puzzle.

The risk-free rate is 1.65 percent on average with low volatility, which is consistent with the empirical evidence. One dimension in which the model deviates from the empirical evidence is the correlation between the risk-free rate and nondurable consumption growth. The risk-free rate is positively correlated with nondurable consumption growth in the model through variation in the expected growth rate of consumption. The lack of such evidence in the data may arise from the fact that the realized real interest rate (i.e., the T-bill rate minus inflation) is an imperfect proxy for the ex ante real interest rate.

\section{E. Predictability of Stock Returns}

If we rearrange the accumulation equation (1) and compute the conditional standard deviation of both sides,

$$
\frac{D_{t-1}}{E_{t-1}}=\frac{\sigma_{t-1}\left(E_{t} / E_{t-1}\right)}{\sigma_{t-1}\left(D_{t} / D_{t-1}\right)} .
$$

This relation between the stock of durables and the conditional volatility of durable expenditure is a natural consequence of durability. A low productivity shock causes the desired future service flow from durable goods to fall, which is accomplished through a reduction in durable expenditure. When the existing stock of durables is relatively high, such a reduction must be more pronounced.

The model therefore identifies two channels for generating predictability of stock returns. First, the intertemporal marginal rate of substitution (22) is more volatile when the stock of durables is relatively 
TABLE 10

Predictability of Excess Returns in the Simulated Model

\begin{tabular}{|c|c|c|c|}
\hline Statistic & $\begin{array}{l}\text { Market } \\
\text { Porfolio }\end{array}$ & $\begin{array}{l}\text { Nondurable- } \\
\text { Good Firm }\end{array}$ & $\begin{array}{l}\text { Durable- } \\
\text { Good Firm }\end{array}$ \\
\hline & \multicolumn{3}{|c|}{ A. Excess Returns } \\
\hline Coefficient & $\begin{array}{c}-1.14 \\
(1.23)\end{array}$ & $\begin{array}{l}-.99 \\
(1.06)\end{array}$ & $\begin{array}{r}-2.17 \\
(2.21)\end{array}$ \\
\hline$t$-statistic & $\begin{array}{c}-1.03 \\
(1.09)\end{array}$ & $\begin{array}{r}-1.04 \\
(1.09)\end{array}$ & $\begin{array}{c}-1.12 \\
(1.07)\end{array}$ \\
\hline \multirow[t]{2}{*}{$R^{2}(\%)$} & $\begin{array}{c}3.59 \\
(4.27)\end{array}$ & $\begin{array}{c}3.63 \\
(4.30)\end{array}$ & $\begin{array}{c}3.86 \\
(4.45)\end{array}$ \\
\hline & \multicolumn{3}{|c|}{ B. Volatility of Excess Returns } \\
\hline Coefficient & $\begin{array}{c}-.72 \\
(.84)\end{array}$ & $\begin{array}{r}-.65 \\
(.73)\end{array}$ & $\begin{array}{r}-1.40 \\
(1.53)\end{array}$ \\
\hline$t$-statistic & $\begin{array}{l}-.96 \\
(1.13)\end{array}$ & $\begin{array}{r}-1.02 \\
(1.13)\end{array}$ & $\begin{array}{c}-1.05 \\
(1.12)\end{array}$ \\
\hline \multirow[t]{2}{*}{$R^{2}(\%)$} & $\begin{array}{c}3.88 \\
(4.83)\end{array}$ & $\begin{array}{c}4.07 \\
(4.97)\end{array}$ & $\begin{array}{c}4.23 \\
(5.09)\end{array}$ \\
\hline & \multicolumn{3}{|c|}{ C. Volatility of Cash Flow Growth } \\
\hline Coefficient & $\begin{array}{l}-.85 \\
(1.01)\end{array}$ & $\begin{array}{c}.55 \\
(.33)\end{array}$ & $\begin{array}{r}-6.96 \\
(4.33)\end{array}$ \\
\hline$t$-statistic & $\begin{array}{c}-1.08 \\
(1.65)\end{array}$ & $\begin{array}{c}3.51 \\
(2.37)\end{array}$ & $\begin{array}{r}-2.32 \\
(1.47)\end{array}$ \\
\hline$R^{2}(\%)$ & $\begin{array}{c}6.40 \\
(7.68)\end{array}$ & $\begin{array}{c}22.15 \\
(16.76)\end{array}$ & $\begin{array}{l}13.75 \\
(8.89)\end{array}$ \\
\hline
\end{tabular}

Note-We use the calibrated model to simulate 10,000 samples, each consisting of 50 annual observations. We run a regression of excess returns, over the risk-free asset, onto the lagged durable expenditure-stock ratio in each sample. In panel A, we report the mean and the standard deviation (in parentheses) of the regression coefficient, the $t$-statistic, and the $R^{2}$ across the simulated samples. Panel B repeats the same exercise for the absolute value of excess returns, and panel $\mathrm{C}$ repeats the same exercise for the absolute value of log cash flow growth. Table 8 reports the parameters of the calibrated model.

high because it depends on the stock of durables as a ratio of nondurable consumption. This common channel is responsible for the predictability of the market portfolio. Second, the conditional volatility of the cash flows of the durable-good firm is increasing in the existing stock of durables. The durable-good firm must therefore earn a higher expected return when the stock of durables is relatively high, as compensation for the higher conditional cash flow risk. This independent channel is responsible for making the stock returns of the durable-good firm more predictable than those of the nondurable-good firm.

To examine these implications of the model, we simulate 10,000 samples, each consisting of 50 annual observations. In each sample, we run a regression of excess returns, over the risk-free asset, onto the durable expenditure-stock ratio. Panel A of table 10 reports the mean and the standard deviation of the regression coefficient, the $t$-statistic, and the $R^{2}$ across the simulated samples. We find that the regression coefficient is negative for both firms, explained by the common channel of pre- 
dictability. More important, the magnitude of the coefficient for the durable-good firm is greater than that for the nondurable-good firm, explained by the independent channel of predictability. Although there is considerable sampling error, as evidenced by the standard deviation of the coefficient across the simulated samples, the model produces results that are consistent with the empirical evidence in table 5 .

In panel $\mathrm{B}$, we regress the absolute value of excess returns onto the lagged durable expenditure-stock ratio in each of the simulated samples. The regression coefficients for both firms are negative, implying that the conditional volatility of stock returns is decreasing in the durable expenditure-stock ratio. More important, the magnitude of the coefficient is larger for the durable-good firm. These patterns are consistent with the empirical evidence in table 6 .

In panel $\mathrm{C}$, we regress the absolute value of cash flow growth onto the lagged durable expenditure-stock ratio in each of the simulated samples. The regression coefficient for the durable-good firm is negative, implying that the conditional volatility of cash flows for the durablegood firm is decreasing in the lagged durable expenditure-stock ratio. In contrast, the conditional volatility of the cash flows for the nondurable-good firm is increasing in the lagged durable expenditure-stock

ratio. These patterns are consistent with the empirical evidence for sales and operating income in table 7.

\section{Estimation of the Euler Equations}

Section II provided evidence that the durability of output is a source of systematic risk that is priced in both the cross section and the time series of expected stock returns. This section formalizes that analysis by estimating a model of risk and return using our five industry portfolios. Specifically, we estimate the preference parameters and test the model through the Euler equations (21) and (24). As is well known, the Euler equations must hold even in an economy in which the production technology is different from the particular model described in Section III. Therefore, this procedure provides a fairly general assessment of the model.

Although the estimation exercise here is similar to that reported in Yogo (2006), there are three key differences. First, we include housing in our measure of the stock of durables, so that our intertemporal marginal rate of substitution is closely related to that in Piazzesi et al. (2007). Second, our measure of the return on wealth includes the value of both consumer durable goods and private residential fixed assets, which were left out of the analysis in Yogo (2006). Finally, our main test assets are the five industry portfolios, whereas Yogo estimated the model on the Fama-French (1992) portfolios and beta-sorted portfolios. Be- 
cause our industry portfolios generate differences in consumption risk by construction, they provide an arguably tougher test for the consumption-based model.

\section{A. Estimation Methodology}

Let $R_{f t}$ denote the 3-month T-bill rate, $R_{i t}(i=1, \ldots, 5)$ denote gross returns on the five industry portfolios, and $z_{t}$ denote a vector of $I$ instrumental variables known in period $t$. Using the methodology developed by Hansen and Singleton (1982), we estimate and test the model through the following moment restrictions:

$$
\begin{gathered}
0=\mathbf{E}\left[\left(M_{t+1} R_{f, t+1}-1\right) z_{t}\right], \\
0=\mathbf{E}\left[M_{t+1}\left(R_{i, t+1}-R_{f, t+1}\right) z_{t}\right], \\
0=\mathbf{E}\left[\left[1-\frac{(1-\delta) M_{t+1} P_{t+1}}{P_{t}}-\frac{\alpha}{(1-\alpha) P_{t}}\left(\frac{D_{t}}{C_{t}}\right)^{-1 / \rho}\right] z_{t}\right] .
\end{gathered}
$$

Equation (35) represents $I$ moment restrictions implied by the Euler equation for the 3-month T-bill. Equation (36) represents $5 I$ moment restrictions implied by the Euler equations for the industry portfolios. Equation (37) represents $I$ moment restrictions implied by the intratemporal first-order condition.

We use annual data for the 1930-2007 sample period. As detailed in Appendix B, our measure of the stock of durables includes private residential fixed assets. In moment restriction (37), we fix $\delta=4.63$ percent to match the annual depreciation rate for durable goods. Using equation (19), we construct an empirical proxy for the return on wealth as a weighted average of returns on durable goods and the CRSP valueweighted portfolio of all NYSE, AMEX, and Nasdaq stocks. In our sample, the average portfolio weight on durable goods is about 71 percent of wealth.

We estimate the model by two-step generalized method of moments (GMM). We use the identity weighting matrix in the first stage and the vector autoregressive heteroskedasticity- and autocorrelation-consistent (VARHAC) covariance matrix estimator in the second stage (Den Haan and Levin 1997). ${ }^{4}$ The instruments are lags of nondurable and service consumption growth, durable expenditure-stock ratio, dividend yield, and a constant. There are a total of 28 moment restrictions to estimate

\footnotetext{
${ }^{4}$ Den Haan and Levin (2000) find that the VARHAC covariance matrix estimator performs better than kernel-based estimators (e.g., Newey and West 1987; Andrews 1991) in various Monte Carlo experiments.
} 
TABLE 11

Estimation of the Preference Parameters through the Euler Equations

\begin{tabular}{|c|c|c|}
\hline Parameter & $\begin{array}{c}\text { 1930-2007 } \\
\text { Annual }\end{array}$ & $\begin{array}{c}1951-2007 \\
\text { Quarterly }\end{array}$ \\
\hline$\beta$ & $\begin{array}{c}.91 \\
(.01)\end{array}$ & $\begin{array}{c}.99 \\
(.15)\end{array}$ \\
\hline$\sigma$ & $\begin{array}{c}.66 \\
(.08)\end{array}$ & $\begin{array}{c}.03 \\
(.01)\end{array}$ \\
\hline$\gamma$ & $\begin{array}{l}16.34 \\
(4.41)\end{array}$ & $\begin{array}{l}231.36 \\
(32.85)\end{array}$ \\
\hline$\rho$ & $\begin{array}{c}.60 \\
(.04)\end{array}$ & $\begin{array}{c}.81 \\
(.23)\end{array}$ \\
\hline$\alpha$ & $\begin{array}{c}.49 \\
(.02)\end{array}$ & $\begin{array}{c}.94 \\
(.04)\end{array}$ \\
\hline Wald test of $\sigma=\rho$ & $\begin{array}{l}1.74 \\
(.19)\end{array}$ & $\begin{array}{r}11.65 \\
(.00)\end{array}$ \\
\hline Wald test of $\sigma=1 / \gamma$ & $\begin{array}{r}102.65 \\
(.00)\end{array}$ & $\begin{array}{l}8.76 \\
(.00)\end{array}$ \\
\hline$J$-test & $\begin{array}{r}27.18 \\
\quad(.25)\end{array}$ & $\begin{array}{c}8.94 \\
(1.00)\end{array}$ \\
\hline \multicolumn{3}{|c|}{$\begin{array}{l}\text { NoTE. - We use the conditional moment restrictions implied by the Euler equations } \\
\text { to estimate the preference parameters of the model by two-step GMM. The test assets } \\
\text { are the 3-month T-bill and five industry portfolios sorted by their primary contribution } \\
\text { to final demand according to the benchmark input-output accounts. All nominal } \\
\text { returns are deflated by the price index for nondurable goods and services. The } \\
\text { instruments are lags of real nondurable and service consumption growth, durable } \\
\text { expenditure-stock ratio, dividend yield, and a constant. Standard errors (in paren- } \\
\text { theses) are based on the VARHAC covariance matrix estimator with automatic lag } \\
\text { length selection (using a maximum lag length of one period) by the Akaike infor- } \\
\text { mation criteria. The } p \text {-values for the Wald test for additive separability }(\sigma=\rho) \text {, the } \\
\text { Wald test for time separability }(\sigma=1 / \gamma) \text {, and the } J \text {-test (i.e., test of overidentifying } \\
\text { restrictions) are reported in parentheses. }\end{array}$} \\
\hline
\end{tabular}

five parameters (i.e., $\beta, \sigma, \gamma, \rho$, and $\alpha$ ). Consequently, there are 23 overidentifying restrictions of the model, which we test through the $J$ test (Hansen 1982).

\section{B. Estimates of the Preference Parameters}

Table 11 reports estimates of the preference parameters. The estimate of the subjective discount factor is $\beta=0.91$ with a standard error of 0.01 . The estimate of the elasticity of intertemporal substitution is $\sigma=0.66$ with a standard error of 0.08 . The estimate of relative risk aversion is $\gamma=16$ with a standard error of 4 . Finally, the estimate of the elasticity of substitution between nondurable and durable goods is $\rho=0.60$ with a standard error of 0.04 . The preference parameters estimated here are almost entirely consistent with those that are necessary for explaining asset prices in the production economy, reported in table 8 . The only exception is that the estimate of the elasticity of intertemporal substitution is somewhat lower than the value used in the calibration. 
The Wald test for the hypothesis of additive separability, $\sigma=\rho$, fails to reject with a $p$-value of 19 percent. However, the Wald test for the hypothesis of time separability, $\sigma=1 / \gamma$, rejects strongly. The $J$-test fails to reject our model at conventional significance levels. To understand the implications of these results for asset prices, note that the intertemporal marginal rate of substitution (22) can be linearized as a threefactor model in nondurable consumption growth, durable consumption growth, and the return on wealth (see Yogo 2006, eq. 18). The restriction $\sigma=\rho$ implies that a two-factor model in nondurable consumption growth and the return on wealth can explain the cross section and the time series of expected returns on the industry portfolios. Thus, our industry portfolios reject standard one-factor models such as the CAPM and the consumption-based CAPM. ${ }^{5}$

Table 11 also reports estimates of the preference parameters using quarterly data for the 1951:1-2007:4 sample period. The disadvantage of quarterly data is that the sample period is shorter. Its potential advantage is that the covariance between consumption and asset returns is more accurately measured than in annual data. The estimate of the elasticity of intertemporal substitution is $\sigma=0.03$ with a standard error of 0.01 . The low elasticity of intertemporal substitution forces a high estimate of the subjective discount factor, which we bound at $\beta=$ 0.99 to ensure finite expected utility. The estimate of relative risk aversion is $\gamma=231$ with a standard error of 33, which is significantly higher than the estimate in annual data. This finding is a natural consequence of the fact that consumption is less volatile and less correlated with stock returns in the 1951-2007 sample period, as reported in table 9. Finally, the estimate of the elasticity of substitution between nondurable and durable goods is $\rho=0.81$ with a standard error of 0.23 . Interestingly, our parameter estimates are quite similar to those reported in Yogo (2006) for a different set of test portfolios and instruments.

The Wald tests for the hypotheses of additive separability as well as time separability reject strongly. These rejections imply that neither the Epstein-Zin (1991) model nor the nonseparable expected utility model can explain the cross section and the time series of expected returns on the industry portfolios. The $J$-test fails to reject our model at conventional significance levels.

\footnotetext{
${ }^{5}$ Our model does not nest the conditional CAPM in which the price of risk for the return on wealth is time varying. Thus, our model can be distinguished from the conditional CAPM in a long sample with a complete set of test assets. In a finite sample, however, our industry portfolios may not be able to reject ad hoc empirical implementations of the conditional CAPM.
} 


\section{Conclusion}

The literature on the cross section of stock returns has documented a number of empirical relations between characteristics, which are often directly related to stock prices or returns, and expected returns. Although these studies provide useful descriptions of stock market data, they provide a limited insight into the underlying economic determinants of stock returns. Consequently, numerous explanations have been proposed for these empirical findings, which include compensation for yet undiscovered economic risk factors (e.g., Fama and French 1993), investor mistakes (e.g., Lakonishok, Shleifer, and Vishny 1994), and data snooping (e.g., Lo and MacKinlay 1990).

Ultimately, stock prices should not be viewed as characteristics by which to rationalize differences in expected returns. Instead, stock prices and expected returns should jointly be explained by more fundamental aspects of firm heterogeneity, such as the demand for their output. This paper has shown that the durability of output is an important characteristic that determines the cross section and the time series of stock returns. Firms that produce durable goods have higher average stock returns, and their expected returns vary more over the business cycle. We suspect that there are other, and perhaps more important, aspects of demand that explain differences in expected stock returns.

\section{Appendix A}

\section{Construction of the Industry Classification}

The construction of the industry classification requires the following tables from the benchmark input-output accounts.

- SIC-IO table: Industry classification of the 1987 benchmark input-output accounts.

- IO table 2: The use of commodities by industries.

- IO table D: Input-output commodity composition of personal consumption expenditures in producers' and purchasers' prices.

The construction of the industry classification proceeds through the following steps.

\section{A. Link from SIC Code to I-O Code}

The SIC-IO table is the key table that links each I-O code to related, and potentially multiple, 1987 SIC codes. The link occurs at various levels of detail from the two- to four-digit SIC code. We exclude the wholesale and retail (SIC codes 5000-5999) and the financial (SIC codes 6000-6999) industries. For wholesale and retail, a detailed breakdown of value added by personal consumption expenditure category is not available in the public data. Similarly, the 
benchmark input-output accounts are not designed to give a precise breakdown of valued added for the financial sector.

\section{B. Link from I-O Commodity to Final Demand}

IO table 2 identifies the I-O commodity composition of each final good measured at producers' prices. The categories of final demand are consumption (I-O code 910000), investment (I-O codes 920000-930000), government expenditures (I-O codes 960000-993009), and net exports (I-O codes 940000-950000). Each I-O commodity potentially contributes to multiple categories of final demand. However, we create a unique link by assigning each I-O commodity to the category of final demand to which it has the highest value added.

We merge the link from SIC code to I-O code with this link from I-O commodity (each identified by an I-O code) to final demand. The merge produces a multiple-to-multiple link between SIC code and final demand. We then aggregate value added over all pairs of SIC code and final demand at the two-, three-, and four-digit levels. The aggregation produces a one-to-one link between SIC code and final demand.

\section{Link from I-O Commodity to Personal Consumption Expenditures}

IO table D identifies the I-O commodity composition of each personal consumption expenditure good measured at producers' prices. The Bureau of Economic Analysis classifies personal consumption expenditures into the following categories of durability: durable goods, nondurable goods, and services. Each I-O commodity potentially contributes to multiple categories of personal consumption expenditures. However, we create a unique link by assigning each I-O commodity to the category of personal consumption expenditures to which it has the highest value added.

We merge the link from SIC code to I-O code with this link from I-O commodity to personal consumption expenditures. The merge produces a multipleto-multiple link between SIC code and personal consumption expenditures. We then aggregate value added over all pairs of SIC code and personal consumption expenditures at the two-, three-, and four-digit levels. The aggregation produces a one-to-one link between SIC code and personal consumption expenditures.

\section{Industry Classification by Final Demand}

We first use the link between SIC code and final demand to classify each SIC industry into mutually exclusive categories: consumption, investment, government expenditures, and net exports. Within the set of industries that are classified as consumption, we then use the link between SIC code and personal consumption expenditures to classify each industry into mutually exclusive categories: durable goods, nondurable goods, and services. 
Appendix B

\section{Macroeconomic Data}

We primarily work with annual macroeconomic data for the 1930-2007 sample period. We also use quarterly data for the 1951:1-2007:4 sample period, only for the purposes of estimating the household's Euler equations in Section V. We construct our data using the following tables from the Bureau of Economic Analysis.

- NIPA table 2.3.3: Real personal consumption expenditures by major type of product, quantity indexes.

- NIPA table 2.3.4: Price indexes for personal consumption expenditures by major type of product.

- NIPA table 2.3.5: Personal consumption expenditures by major type of product.

- NIPA table 5.3.3: Real private fixed investment by type, quantity indexes.

- NIPA table 5.3.4: Price indexes for private fixed investment by type.

- NIPA table 5.3.5: Private fixed investment by type.

- NIPA table 5.7.5A: Private inventories and domestic final sales of business by industry.

- NIPA table 5.7.5B: Private inventories and domestic final sales by industry.

- NIPA table 7.1: Selected per capita product and income series in current and chained dollars.

- Fixed assets table 5.1: Current-cost net stock of residential fixed assets by type of owner, legal form of organization, industry, and tenure group.

- Fixed assets table 8.1: Current-cost net stock of consumer durable goods.

Departing from the national accounts convention, we account for housing as part of durable goods instead of services. Nondurable and service consumption is the properly chain-weighted sum of real personal consumption expenditures on nondurable goods, plus services, minus housing services. Durable expenditure is the properly chain-weighted sum of real personal consumption expenditures on durable goods and real private residential fixed investment.

The stock of durables is the sum of the net stock of consumer durable goods and the net stock of private residential fixed assets. ${ }^{6}$ The data for the stock of durables are available only at an annual frequency, measured at each year end. We therefore construct a quarterly series using quarterly data on real durable expenditure. We do so by computing a constant depreciation rate within each year so that the data satisfy the accumulation equation (1). The average depreciation rate for durable goods, implied by the construction, is 1.39 percent per

${ }^{6}$ Private residential fixed assets do not include the value of residential land, which is an intentional omission in our construction because durable goods in our model must be reproducible. We have tried an alternative construction that includes the value of residential land, assuming that the price of land is perfectly correlated with that of structures (see Piazzesi et al. 2007). The substance of our findings is the same under this alternative data construction. 
quarter. We define the durable expenditure-stock ratio as the ratio of net durable expenditure to the stock of durables, that is, $\left(D_{t}-D_{t-1}\right) / D_{t}{ }^{7}$

We use the price index for nondurable goods and services to deflate all nominal asset returns and cash flow growth. Note that our deflation methodology is consistent with our modeling convention that the nondurable good is the numeraire in the economy. In computing growth rates, we first divide all quantities by the population. In matching consumption growth to returns at both an annual and quarterly frequency, we use the "beginning-of-period" timing convention following Campbell (2003). Specifically, the asset return in period $t$ is matched to the growth rate in consumption flow from period $t$ to $t+1$.

\section{Appendix C}

\section{Solution of the General Equilibrium Model}

\section{A. Central Planner's Problem}

We first restate the general equilibrium model as a central planner's problem. The central planner chooses optimal nondurable consumption, durable expenditure, and inventory investment in order to maximize the household's objection function. The Bellman equation for the problem is

$$
\begin{aligned}
J_{t} & =J\left(D_{t-1}, D_{I, t-1}, X_{t}\right) \\
& =\max _{C_{t} E_{t}, E_{t t}}\left\{(1-\beta) u\left(C_{t}, D_{t}\right)^{1-1 / \sigma}+\beta \mathbf{E}_{t}\left[J_{t+1}^{1-\gamma}\right]^{1 / \kappa}\right\}^{1 /(1-1 / \sigma)} .
\end{aligned}
$$

The laws of motion for the state variables are given by equations (1), (4), and (10).

As shown in Yogo (2006, app. B), the value of a claim to the household's consumption expenditures is related to the value function through the equation

$$
V_{M t}=\frac{C_{t}^{1 / \sigma} J_{t}^{1-1 / \sigma}}{(1-\beta)(1-\alpha) v\left(D_{t} / C_{t}\right)^{1 / \rho-1 / \sigma}}-C_{t}-P_{t} D_{t} .
$$

\section{B. Rescaling the General Equilibrium Model}

To make the model stationary, we normalize all policy and state variables by aggregate productivity raised to the power $\chi$, which is related to the production parameters through equation (31). Let $\hat{C}_{t}=C_{t} / X_{t}^{\chi}, \hat{E}_{t}=E_{t} / X_{t}^{\chi}, \hat{E}_{I t}=E_{I t} / X_{t}^{\chi}$, $\hat{D}_{t}=D_{t} / X_{t}^{\chi}$, and $\hat{D}_{I t}=D_{I t} / X_{t}^{\chi}$. Let $\Delta X_{t+1}=X_{t+1} / X_{t}$ denote the growth rate of aggregate productivity.

\footnotetext{
${ }^{7}$ An alternative definition is the ratio of gross durable expenditure to the stock of durables, i.e., $E_{t} / D_{t}$. This series is nonstationary because of a slow decline in the depreciation rate for private residential fixed assets during the sample period.
} 
By homotheticity, we can normalize the value function as

$$
\begin{aligned}
\hat{J}_{t} & =\frac{J_{t}}{X_{t}^{\chi}}=\hat{J}\left(\hat{D}_{t-1}, \hat{D}_{I, t-1}, \Delta X_{t}\right) \\
& =\max _{\hat{C}_{t} \hat{E}_{t} \hat{E}_{t}}\left\{(1-\beta) u\left(\hat{C}_{t}, \hat{D}_{t}\right)^{1-1 / \sigma}+\beta \mathbf{E}_{t}\left[\left(\Delta X_{t+1}^{\chi} \hat{J}_{t+1}\right)^{1-\gamma}\right]^{1 / \kappa}\right\}^{1 /(1-1 / \sigma)} .
\end{aligned}
$$

The laws of motion for the state variables are given by

$$
\begin{aligned}
& \hat{D}_{t}=(1-\delta) \frac{\hat{D}_{t-1}}{\Delta X_{t}^{\chi}}+\hat{E}_{t}, \\
& \hat{D}_{I t}=(1-\delta) \frac{\hat{D}_{I, t-1}}{\Delta X_{t}^{\chi}}+\hat{E}_{I t}, \\
& \Delta X_{t}=\exp \left\{\mu+z_{t}+e_{t}\right\} .
\end{aligned}
$$

The relative price of the durable good is given by

$$
P_{t}=\frac{\theta_{C} \hat{C}_{t}^{1-1 / x}}{\theta_{E} \hat{Y}_{E t}^{1-1 /\left(\eta \theta_{E}\right)}\left(\hat{D}_{I, t-1} / \Delta X_{t}^{\chi}\right)^{\theta_{I} / \theta_{E}}},
$$

where the output of the durable-good firm is

$$
\hat{Y}_{E t}=\frac{Y_{E t}}{X_{t}^{\chi}}=\hat{E}_{t}+\hat{E}_{I t}+\frac{\tau \Delta X_{t}^{\chi}\left(\hat{D}_{I t}-\hat{D}_{I, t-1} / \Delta X_{t}^{\chi}\right)^{2}}{2 \hat{D}_{I, t-1}} .
$$

The user cost of the durable good is given by equation (20), where equation (C2) allows us to express the intertemporal marginal rate of substitution as

$$
M_{t+1}=\beta\left(\frac{\Delta X_{t+1}^{\chi} \hat{C}_{t+1}}{\hat{C}_{t}}\right)^{-1 / \sigma}\left[\frac{v\left(\hat{D}_{t+1} / \hat{C}_{t+1}\right)}{v\left(\hat{D}_{t} / \hat{C}_{t}\right)}\right]^{1 / \rho-1 / \sigma}\left\{\frac{\left(\Delta X_{t+1}^{\chi} \hat{J}_{t+1}\right)^{1-1 / \sigma}}{\mathbf{E}_{t}\left[\left(\Delta X_{t+1}^{\chi} \hat{J}_{t+1}\right)^{1-\eta}\right]^{1 / \kappa}}\right\}^{\kappa-1} .
$$

The rental prices for the factors of production are given by

$$
\begin{gathered}
\hat{W}_{t}=\frac{W_{t}}{X_{t}^{\chi}}=\eta\left(\theta_{C} \hat{C}_{t}+\theta_{E} P_{t} \hat{Y}_{E t}\right), \\
\hat{W}_{C t}=\frac{W_{C t}}{X_{t}^{\chi}}=\eta\left(1-\theta_{C}\right) \mathbf{E}_{t}\left[M_{t+1} \Delta X_{t+1}^{\chi} \hat{C}_{t+1}\right], \\
\hat{W}_{E t}=\frac{W_{E t}}{X_{t}^{\chi}}=\eta\left(1-\theta_{E}-\theta_{t}\right) \mathbf{E}_{t}\left[M_{t+1} \Delta X_{t+1}^{\chi} P_{t+1} \hat{Y}_{E, t+1}\right] .
\end{gathered}
$$

The first-order conditions for nondurable consumption, durable expenditure, and inventory investment are given by

$$
\hat{W}_{t}=\chi \hat{C}_{t}^{1-1 / \chi},
$$




$$
\begin{gathered}
Q_{t}=\frac{\alpha}{1-\alpha}\left(\frac{\hat{D}_{t}}{\hat{C}_{t}}\right)^{-1 / \rho}, \\
Q_{t}=\frac{\eta \theta_{I} \mathbf{E}_{t}\left[M_{t+1} \Delta X_{t+1}^{\chi} P_{t+1} \hat{Y}_{E, t+1}\right]}{\hat{D}_{I t}}-\tau P_{t}\left(\frac{\Delta X_{t}^{\chi} \hat{D}_{I t}}{\hat{D}_{I, t-1}}-1\right) \\
+\frac{\tau}{2} \mathbf{E}_{t}\left[M_{t+1} P_{t+1}\left[\left(\frac{\Delta X_{t+1}^{\chi} \hat{D}_{I, t+1}}{\hat{D}_{I t}}\right)^{2}-1\right]\right] .
\end{gathered}
$$

\section{Numerical Algorithm}

We discretize the state space and numerically solve the central planner's problem. Starting with an initial guess for the policy functions $\left(\hat{C}_{0}, \hat{E}_{0}, \hat{E}_{I 0}\right)$, we solve the dynamic program through the following recursion.

1. Iterate on equation (C3) to compute the value function $\hat{J}_{i}$ corresponding to the current policy functions $\left(\hat{C}_{i}, \hat{E}_{i}, \hat{E}_{i}\right)$.

2. Using the value function $\hat{J}_{i}$, update the policy functions $\left(\hat{C}_{i+1}, \hat{E}_{i+1}, \hat{E}_{I, i+1}\right)$ as a solution to the system of equations (C13), (C14), and (C15).

3. If $\left\|\hat{C}_{i+1}-\hat{C}_{i}\right\|+\left\|\hat{E}_{i+1}-\hat{E}_{i}\right\|+\left\|\hat{E}_{I, i+1}-\hat{E}_{I i}\right\|$ is less than the convergence criteria, stop. Otherwise, return to step 1 .

We use the solution to the central planner's problem to compute the intertemporal marginal rate of substitution (9) and cash flows:

$$
\begin{gathered}
\hat{\Pi}_{C t}=\frac{\Pi_{C t}}{X_{t}^{\chi}}=\left(1-\eta \theta_{C}\right) \hat{C}_{t}-\hat{W}_{C t}, \\
\hat{\Pi}_{E t}=\frac{\Pi_{E t}}{X_{t}^{\chi}}=P \hat{E}_{t}-\eta \theta_{E} P_{t} \hat{Y}_{E t}-\hat{W}_{E t} .
\end{gathered}
$$

We then compute firm value by iterating on the Euler equations:

$$
\begin{aligned}
\hat{V}_{C t} & =\frac{V_{C t}}{X_{t}^{\chi}}=\hat{V}_{C}\left(\hat{D}_{t-1}, \hat{D}_{I, t-1}, \Delta X_{t}\right) \\
& =\mathbf{E}_{t}\left[M_{t+1} \Delta X_{t+1}^{\chi}\left(\hat{V}_{C, t+1}+\hat{\Pi}_{C, t+1}\right)\right], \\
\hat{V}_{E t} & =\frac{V_{E t}}{X_{t}^{\chi}}=\hat{V}_{E}\left(\hat{D}_{t-1}, \hat{D}_{I, t-1}, \Delta X_{t}\right) \\
& =\mathbf{E}_{t}\left[M_{t+1} \Delta X_{t+1}^{\chi}\left(\hat{V}_{E, t+1}+\hat{\Pi}_{E, t+1}\right)\right] .
\end{aligned}
$$




\section{References}

Andrews, Donald W. K. 1991. "Heteroskedasticity and Autocorrelation Consistent Covariance Matrix Estimation." Econometrica 59 (3): 817-58.

Bansal, Ravi, and Amir Yaron. 2004. "Risks for the Long Run: A Potential Resolution of Asset Pricing Puzzles." J. Finance 59 (4): 1481-1509.

Banz, Rolf W. 1981. "The Relationship between Return and Market Value of Common Stocks.” J. Financial Econ. 9 (1): 3-18.

Basu, Sanjoy. 1983. "The Relationship between Earnings Yield, Market Value, and Return for NYSE Common Stocks: Further Evidence.” J. Financial Econ. 12 (1): 129-56.

Basu, Susanto, and John G. Fernald. 1997. "Returns to Scale in U.S. Production: Estimates and Implications." J.P.E. 105 (2): 249-83.

Baxter, Marianne. 1996. "Are Consumer Durables Important for Business Cycles?" Rev. Econ. and Statis. 78 (1): 147-55.

Berk, Jonathan B., Richard C. Green, and Vasant Naik. 1999. "Optimal Investment, Growth Options, and Security Returns.” J. Finance 54 (5): 1553-1607.

Bhandari, Laxmi Chand. 1988. "Debt/Equity Ratio and Expected Common Stock Returns: Empirical Evidence.” J. Finance 43 (2): 507-28.

Bils, Mark, and James A. Kahn. 2000. "What Inventory Behavior Tells Us about Business Cycles." A.E.R. 90 (3): 458-81.

Bils, Mark, and Peter J. Klenow. 1998. "Using Consumer Theory to Test Competing Business Cycle Models.” J.P.E. 106 (2): 233-61.

Black, Fischer, Michael C. Jensen, and Myron Scholes. 1972. "The Capital Asset Pricing Model: Some Empirical Tests." In Studies in the Theory of Capital Markets, edited by Michael C. Jensen, 79-121. New York: Praeger.

Boudoukh, Jacob, Roni Michaely, Matthew Richardson, and Michael R. Roberts. 2007. "On the Importance of Measuring Payout Yield: Implications for Empirical Asset Pricing." J. Finance 62 (2): 877-915.

Breeden, Douglas T., Michael R. Gibbons, and Robert H. Litzenberger. 1989. "Empirical Test of the Consumption-Oriented CAPM." J. Finance 44 (2): 23162.

Bureau of Economic Analysis. 1994. "Benchmark Input-Output Accounts for the U.S. Economy, 1987." Survey Current Bus. 4:73-115.

Burnside, Craig, Martin Eichenbaum, and Sergio Rebelo. 1995. "Capital Utilization and Returns to Scale." In NBER Macroeconomics Annual 1995, edited by Ben S. Bernanke and Julio J. Rotemberg, 67-110. Cambridge, MA: MIT Press.

Campbell, John Y. 1991. "A Variance Decomposition for Stock Returns." Econ. J. 101 (405): 157-79.

. 2003. "Consumption-Based Asset Pricing." In Handbook of the Economics of Finance, vol. 1B, edited by George M. Constantinides, Milton Harris, and René M. Stulz, 801-85. Amsterdam: Elsevier.

Carlson, Murray, Adlai Fisher, and Ron Giammarino. 2004. "Corporate Investment and Asset Price Dynamics: Implications for the Cross-Section of Returns." J. Finance 59 (6): 2577-2603.

Cochrane, John H. 1991. "Production-Based Asset Pricing and the Link between Stock Returns and Economic Fluctuations.” J. Finance 46 (1): 209-37.

Daniel, Kent, and Sheridan Titman. 1997. "Evidence on the Characteristics of Cross Sectional Variation in Stock Returns." J. Finance 52 (1): 1-33.

Davis, James L., Eugene F. Fama, and Kenneth R. French. 2000. "Characteristics, Covariances, and Average Returns: 1929 to 1997.” J. Finance 55 (1): 389-406.

Den Haan, Wouter J., and Andrew T. Levin. 1997. “A Practitioner's Guide to 
Robust Covariance Matrix Estimation.” In Handbook of Statistics, vol. 15, edited by G. S. Maddala and C. R. Rao, 299-342. Amsterdam: Elsevier.

. 2000. "Robust Covariance Matrix Estimation with Data-Dependent VAR Prewhitening Order.” Technical Working Paper no. 255, NBER, Cambridge, MA.

Dunn, Kenneth B., and Kenneth J. Singleton. 1986. "Modeling the Term Structure of Interest Rates under Non-separable Utility and Durability of Goods." J. Financial Econ. 17 (1): 27-55.

Eichenbaum, Martin, and Lars Peter Hansen. 1990. "Estimating Models with Intertemporal Substitution Using Aggregate Time Series Data." J. Bus. and Econ. Statis. 8 (1): 53-69.

Epstein, Larry G., and Stanley E. Zin. 1991. "Substitution, Risk Aversion, and the Temporal Behavior of Consumption and Asset Returns: An Empirical Analysis.” J.P.E. 99 (2): 263-86.

Fama, Eugene F., and Kenneth R. French. 1992. "The Cross-Section of Expected Stock Returns." J. Finance 47 (2): 427-65.

- 1993. "Common Risk Factors in the Returns on Stocks and Bonds." J. Financial Econ. 33 (1): 3-56.

- 1997. "Industry Costs of Equity." J. Financial Econ. 43 (2): 153-93.

Fama, Eugene F., and James D. MacBeth. 1973. "Risk, Return, and Equilibrium: Empirical Tests." J.P.E. 81 (3): 607-36.

Gomes, João, Leonid Kogan, and Lu Zhang. 2003. "Equilibrium Cross Section of Returns.” J.P.E. 111 (4): 693-732.

Gourio, Francois. 2005. "Operating Leverage, Stock Market Cyclicality, and the Cross Section of Returns." Working paper, Boston Univ.

Hansen, Lars Peter. 1982. "Large Sample Properties of Generalized Method of Moments Estimators." Econometrica 50 (4): 1029-54.

Hansen, Lars Peter, and Kenneth J. Singleton. 1982. "Generalized Instrumental Variables Estimation of Nonlinear Rational Expectations Models." Econometrica 50 (5): 1269-86.

Jegadeesh, Narasimhan, and Sheridan Titman. 1993. "Returns to Buying Winners and Selling Losers: Implications for Stock Market Efficiency.” J. Finance 48 (1): 65-91.

Kogan, Leonid. 2001. "An Equilibrium Model of Irreversible Investment." J. Financial Econ. 62 (2): 201-45.

—. 2004. "Asset Prices and Real Investment." J. Financial Econ. 73 (3): 41131

Kydland, Finn E., and Edward C. Prescott. 1982. "Time to Build and Aggregate Fluctuations." Econometrica 50 (6): 1345-70.

Lakonishok, Josef, Andrei Shleifer, and Robert W. Vishny. 1994. "Contrarian Investment, Extrapolation, and Risk." J. Finance 49 (5): 1541-78.

Lamont, Owen A. 2001. "Economic Tracking Portfolios." J. Econometrics 105 (1): $161-84$.

Lo, Andrew W., and A. Craig MacKinlay. 1990. "Data-Snooping Biases in Tests of Financial Asset Pricing Models.” Rev. Financial Studies 3 (3): 431-67.

Newey, Whitney K., and Kenneth D. West. 1987. "A Simple, Positive Semi-definite, Heteroskedasticity and Autocorrelation Consistent Covariance Matrix." Econometrica 55 (3): 703-8.

Ogaki, Masao, and Carmen M. Reinhart. 1998. "Measuring Intertemporal Substitution: The Role of Durable Goods." J.P.E. 106 (5): 1078-98.

Pakoš, Michal. 2004. "Asset Pricing with Durable Goods and Non-homothetic Preferences.” Working paper, Univ. Chicago. 
Papanikolaou, Dimitris. 2008. "Investment-Specific Technological Change and Asset Prices.” Working paper, Northwestern Univ.

Petersen, Bruce, and Steven Strongin. 1996. "Why Are Some Industries More Cyclical than Others?” J. Bus. and Econ. Statis. 14 (2): 189-98.

Piazzesi, Monika, Martin Schneider, and Selale Tuzel. 2007. "Housing, Consumption and Asset Pricing." J. Financial Econ. 83 (3): 531-69.

Rosenberg, Barr, Kenneth Reid, and Ronald Lanstein. 1985. "Persuasive Evidence of Market Inefficiency.” J. Portfolio Management 11 (1): 9-17.

Shiller, Robert J. 1993. Macro Markets. Clarendon Lectures in Economics. New York: Oxford Univ. Press.

Tuzel, Selale. 2005. "Corporate Real Estate Holdings and the Cross Section of Stock Returns." Working paper, Univ. Southern California.

Weil, Philippe. 1990. "Nonexpected Utility in Macroeconomics." Q.J.E. 105 (1): 29-42.

Yogo, Motohiro. 2006. "A Consumption-Based Explanation of Expected Stock Returns.” J. Finance 61 (2): 539-80. 